\title{
THE ACtUARIAL BALANCE SHEET FOR PAY-As-YOU-GO FINANCE: SOLVENCY INDICATORS FOR SPAIN AND SWEDEN
}

\author{
MARÍA DEL CARMEN BOADO-PENAS \\ SALVADOR VALDÉS-PRIETO \\ CARLOS VIDAL-MELIÁ
}

CESIFO WORKING PAPER NO. 2182

CATEgORY 1: Public FinANCE

JANUARY 2008

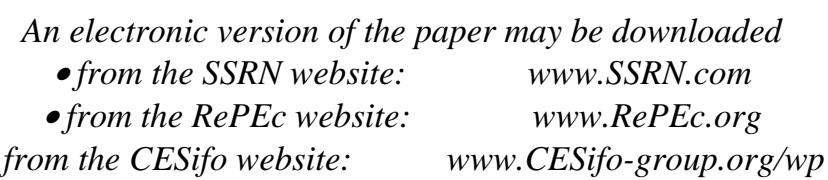




\title{
THE ACTUARIAL BALANCE SHEET FOR PAY-AS-YOU-GO FINANCE: SOLVENCY INDICATORS FOR SPAIN AND SWEDEN
}

\begin{abstract}
This paper provides the first estimate of the actuarial balance of the Spanish contributory pension system for the old age contingency, based on official data. The novel entry in the balance sheet, named "Contribution Asset" or "Hidden Asset", is at the centre of the theoretical discussion. A comparison between the official balance sheet for the Swedish national account system and our balance sheet for the Spanish system is also provided. The main finding is that the Spanish pension system has an insolvency rate of $31.4 \%$. The policy implication is that unless current legislation is reformed, Spanish taxpayers (the plan sponsor) should count on making transfers to the pension system with a present discounted value of $31.4 \%$ of current liabilities. Moreover, a comparison of the consecutive balance sheets for 2001-06 shows that the degree of insolvency is growing over time, even though the cash-flow outcome has improved over the same period. Taking steps to reverse this trend and restore solvency is in the Spanish taxpayers' interest, and possibly also in the interest of those in the European Union who recognise that there is a chance that they may have to support the Spanish budget in the future.
\end{abstract}

JEL Code: H55, J26, M49.

Keywords: retirement, pay-as-you-go system, accountancy, solvency, pensions, Spain.

María del Carmen Boado-Penas

Department of Financial Economics and

Actuarial Science, University of Valencia

Avenida de los Naranjos s.n. 46022 Valencia, Spain

mcboado@hotmail.com
Salvador Valdés-Prieto

Institute of Economics

Catholic University of Chile

Av. Vicuña Mackenna 4860

Macul, Santiago

Chile, postal code 7820436

svaldes@faceapuc.cl

\author{
Carlos Vidal-Meliá \\ Department of Financial Economics and Actuarial Science \\ University of Valencia \\ Avenida de los Naranjos s.n. 46022 Valencia \\ Valencia, Spain \\ carlos.vidal@uv.es
}

The authors are grateful for the financial assistance received from the Ministry of Labour and Social Affairs (Ministerio de Trabajo y Asuntos Sociales) project 2005-138, from the Ministry of Education and Science (Ministerio de Educación y Ciencia) project SEJ2006-05051 and from the Valencian Economic Research Institute (Instituto Valenciano de Investigaciones Económicas), selected external research grants 2007. We would also like to thank Almudena Durán, Antonio Millán, Miguel Angel Peña and Alicia de las Heras for the data provided relating to pensioners and contributors in the Spanish public pension system; Ole Settergren and Boguslaw D. Mikula (Försäkringskassan - The Swedish Social Insurance Agency) for valuable comments, information and explanations about the Swedish pension system; Vicente Meneu-Ferrer, Francisco MuñozMurgui and Silviu Glavan for their comments; Juan Manuel Pérez-Salamero for his help regarding the treatment of the data; and Peter Hall for his English support. Special thanks to Inmaculada Domínguez-Fabián, who made an active contribution to previous versions of the paper. Any errors are entirely due to the authors. 


\section{Introduction.}

Three important issues in pension finance are the social demand for transparency in the management of the finances of public or mandatory systems, the advantages of immunising the pay-as-you-go system against some of the political risk to which it is subject ${ }^{1}$, and the desire to gain credibility among participants (contributors and pensioners) in the sense of harmonising their expectation with the economic realties of the pension plan ${ }^{2}$. All these issues point towards the value of new financial management instruments and indicators for old-age pension plans ${ }^{3}$.

The actuarial balance sheet is an instrument that can provide an attractive response to these three issues. Publishing the actuarial balance sheet may also supply a positive incentive to improve financial management, because it would allow opinion leaders to discuss the size and implications of fiscal risks originating in the pension system, acknowledging its long planning horizon. The relatively short-term vision of both politicians and voters is frequently at odds with the economic reality of a system with an indefinite time horizon. These indicators may help sidestep the difference between the planning horizons of the voters and politicians and of the system itself.

The actuarial balance sheet may also help neutralise and/or minimise populism with regard to pensions. Valdés-Prieto (2006) defines this type of populism as a form of competition between politicians in which voters are offered subsidies and higher pensions without the voters appreciating that it is they themselves that will pay through higher taxes, higher contributions or a higher rate of inflation. In the case of pensions, these negative effects are easy to conceal if the impact of a policy measure on current cash flow is nil or positive. This problem can be alleviated by comparing the balance sheets of the pension system under alternative policies, because the balance sheet shows the impact of those policies on the plan's net worth. This is the full economic impact of the policy, which may be quite different from the impact on the annual cash flow over the electoral horizon.

The actuarial balance sheet has been developed and applied by Sweden since 2001. Thanks to this leadership, Sweden has endowed its pay-as-you-go financed pensions with indicators and information which previously existed only for pensions financed by full funding. The result has been an extraordinary level of transparency. Political risk seems to have fallen (less populism in pensions) insofar as the budgetary tensions generated by the pension system can be forecasted and acted upon with longer lead times. In addition to this, Sweden has legislated an automatic balance mechanism for financial imbalances in its pension system. This mechanism is based on the solvency indicator that emerges from the actuarial balance sheet, which is the solvency ratio.

In Japan, Takayama (2005), has also begun to use an actuarial balance sheet as the fundamental tool for analysing proposed reforms to the pension system. In the U.S., the Board of Trustees of the Federal Old-Age and Survivors Insurance and Disability Insurance Trust Funds has been compiling the elements needed to build an actuarial balance sheet since 1965, and since 2002 it has added stochastic simulations to its reports (BOT, 2007).

This paper has a double objective. On the one hand it shows the usefulness of the actuarial balance sheet as an indicator of the solvency, sustainability or financial solidity of any pay-asyou-go financed pension system. The examples developed here, jointly with transparency, confirm its potential to provide positive incentives to improve financial management by increasing the politicians' planning horizon. On the other hand, this paper offers the first

\footnotetext{
${ }^{1}$ Definitions of political risk in pay-as-you-go finance are not uniform in the specialised literature. Political risk was defined by Diamond (1994), who considered it to be decisions made by politicians. Valdés-Prieto (2000) emphasised that the planning horizon of politicians (4-6 years) is much shorter than the horizon of the pension system.

${ }^{2}$ Besley and Prat (2005) have point out that one of the main problems in pension policy is to develop an institutional framework that guarantees that public (and private) pensions promises are kept. Pensions arrangements have been governed by highly incomplete contractual arrangements. According to Boeri et al. (2001) the European PAYG model faces serious problems from the point of view of credibility.

${ }^{3}$ Holzmann et al. (2004) argue that sound reporting of a government's pension promises would increase its financial credibility. Rating agencies would not necessarily reduce their grading of the outstanding explicit public debt when a government provides more financial information about fiscal risks.
} 
estimate, based on official data, of the actuarial balance sheet of the Spanish contributory retirement pension system, which is financed by the pay-as-you-go method.

The structure of the paper is as follows: The second section explains the actuarial balance sheet for a pension system financed by the pay-as-you-go method and provides both fundamental and intuitive explanations of the entry entitled "Contribution Asset". The third section summarises the published balance sheets of the Swedish pension system and analyses how they have evolved over the period 2001-2006. In the fourth section balance sheets are compiled for the retirement contingency of the Spanish contributory pension system, based on official data supplied by the Ministry of Labour and Social Affairs (Ministerio de Trabajo y Asuntos Sociales, MTAS) for the period 2001-2006. The Spanish balance sheets are then compared with those of Sweden, focusing on solvency. Section 5 provides concluding comments. Four appendices show how the Contribution Asset emerges in discrete time, summarise the "Hidden Asset" literature, present a sensitivity analysis of the Spanish actuarial balance sheet with regard to changes in the projected growth rate of average real salaries, and provide information regarding the basic parameters of the Spanish contributory pension system.

\section{The actuarial balance sheet of a pay-as-you-go pension system.}

The actuarial balance sheet of the pay-as-you-go pension system is the financial statement showing the present discounted value of the pension system's benefit promises to contributors and pensioners at a particular date (liabilities), together with the amounts of the various assets (financial, real and contribution-based) that back up those promises. A major difference between full funding and pay-as-you-go finance is that in the former only financial and/or real assets protected by property rights appear on the assets side. With pure pay-as-you-go finance, however, only the "Contribution Asset" or the "Hidden Asset" appears. This economic asset is not protected by property rights in favour of the pension institution. If the amount of this asset is reduced by new legislation, the State does not have to compensate the pension institution for the losses inflicted, due to the absence of property rights.

The main aim of the actuarial balance sheet is to give a true and fair view of the system's capital at the beginning and the end of the financial year and, by comparing these figures, to determine the result. In any case it contributes to management and external information since it is useful not only for the authority governing the system but also for contributors and pensioners as a whole, and also for whichever body guarantees payment, i.e. for the State along with the contributors it represents.

The main entries on the actuarial balance sheet are those shown in Table 1. This structure is valid for any degree of funding: pure, partial and nil, the latter being equivalent to pure pay-asyou-go.

\begin{tabular}{|c|c|}
\hline \multicolumn{2}{|c|}{ TABLE 1 } \\
Main entries on the balance sheet of a pay-as-you-go system (in value terms) \\
\hline ASSETS & LIABILITIES \\
\hline Financial and Real Assets & Liability to Pensioners \\
\hline Contribution Asset (Hidden Asset) & Liability to Contributors \\
\hline Accumulated Deficit & Accumulated Surplus \\
\hline Total Assets & Total Liabilities \\
\hline
\end{tabular}

In general terms it can be said that a pay-as-you-go pension system is reasonably solvent, and that therefore at the date of the balance sheet the participants should have a realistic expectation of receiving the benefits that have been promised, without the sponsor of the system (the State) having to make non-statutory contributions, as long as: (Financial and Real Assets + Contribution Asset or Hidden Asset) $\geq$ (Liability to Pensioners + Liability to Contributors). This condition implies that the accumulated deficit must be nil or negative or that the solvency ratio, defined as the relation between the assets and liabilities of the system, must be equal to or greater than one. If the accumulated deficit is positive, the pension system is insolvent (partially solvent) (solvency ratio $<1$ ). It means that at some point in the future the sponsor will be forced 
to allocate extraordinary funds to cover the deficit, or that the promises made to some of the participants will be at least partially broken.

\section{Entries on the assets side.}

The novel entry on the pay-as-you-go balance sheet is called the "Contribution Asset" by Settergren (2001, 2003), Settergren and Mikula (2005) and the literature spawned by the Swedish Social Insurance Agency. This entry is called the "Hidden Asset" by Valdés-Prieto (2002), the "Hidden Tax" by others such as Lüdecke (1988), Sinn (1990, 2000) and Lindbeck and Persson (2003), Geanakoplos et al. (1998) and the "Implicit Tax on Pensions" by Cigno (2006) and Disney (2004). "Hidden Asset", "Hidden Tax" and "Implicit Tax on Pensions" must be taken as synonyms. Cigno's (2006) definition, for example, of it being the difference between the present value of future contributions and the present value of future pensions with an infinite horizon is equivalent to the definition given by Valdés-Prieto (2002) and others, which is based on excess contribution.

The discrepancy in name between the "Contribution Asset" and the "Hidden Asset" is justified because these concepts are different, as explained below and in Appendices 1 and 2.

The "Contribution Asset" and the "Hidden Asset" cannot appear on the actuarial balance sheet of the pay-as-you-go system at the same time. They occupy the same place on the balance sheet and are both based on the estimation of future contributions, but, as will be seen below, the "Contribution Asset" uses as discount rate the internal rate of return for each generation living in the steady state, so it needs no recourse to the interest rate in the financial market. The "Hidden Asset", in contrast, despite being applied to the pay-as-you-go system, must use the rate of discount observed in the financial markets, so it can be determined in dynamically efficient economies ${ }^{4}$.

The use of one or the other of these concepts usually implies the use of different discount rates as hypotheses for calculating the actuarial liabilities, and consequently their size is affected.

The presence of the Contribution (Hidden Asset) in the balance sheet counters those who discredit pure and partial pay-as-you-go finance by claiming that it is always "bankrupt" or insolvent. This claim is based on accepting the system's liabilities but ignoring the assets implicit in contributions, which exist under the pay-as-you-go financing method when aggregate flows of contribution and benefits are not too far from balance.

\section{The Contribution Asset}

The Contribution Asset is derived from linking the assets and liabilities of the pension system. For the case of pure pay-as-you-go (when the degree of funding is zero), consider a pension system in a steady-state scenario and in cash-flow equilibrium. The cash flow equilibrium repeats itself every period because of the steady-state assumption. Therefore, the ratio of assets to liabilities must be one, regardless of the level and sequence of discount rates. Because the assets and the liabilities are equal, calculating the closed-group liability based on the main characteristics of the pension system and the main features of the economy and demography, such as growth rate $\mathrm{G}$ of the contribution base, also produces an estimate of the Contribution Asset's size. This follows from the balance sheet identity. This method identifies the size of the Asset without delving into the origin or economic meaning of the cash flows that support it.

Consider representing the benefit formula with a limited set of parameters, such as pension age, replacement rate for the first pension, pension indexation rate, earnings base to which the replacement rate is applied; and representing the economy and the demography within which the pension system operates with another limited set of parameters, such as life expectancy, a

\footnotetext{
${ }^{4}$ An economy will suffer from dynamic inefficiency when the growth rate of GDP is equal to or greater than the risk-adjusted, longterm real rate of interest in the financial markets.

${ }^{5}$ See Appendix 1.
} 
fertility-driven population growth rate $(\gamma)$, a growth rate of average covered earnings in real terms (g), and a discount rate (d) that are constant over time. In any steady state without periodic contributions from the sponsor, the internal rate of return paid by a pure pay-as-you-go system to participants is $g+\gamma=\mathrm{G}$, where $\mathrm{G}$ is the growth rate of the contribution base and also the growth rate of GDP. Under these assumptions and imposing the cash-flow equilibrium condition, the closed-group liability can be expressed as a simple product:

$$
\stackrel{\overbrace{V_{t}}^{\text {Liabilities }}}{=}=\underbrace{f(\text { benefit parameters, } \gamma, g, d) \cdot C_{t}}_{\text {Assets }}
$$

with $V_{t}$ being the amount of accrued liabilities at date $\mathrm{t}$ (a stock), $C_{t}$ being the amount of contribution revenue in year $\mathrm{t}$ (a flow), and $\mathrm{f}\left({ }^{\circ}\right)$ being a function that does not depend on the parameters that determine the size of contribution revenue. This function is called "turnover duration" (TD) by Settergren and Mikula (2005).

Equation 1 can be reinterpreted in an intuitive way by noting that contribution revenue is proportional to the contribution rate $\theta$. Given that the liability is also equal to the Contribution Asset in the assumed steady state, then the maximum level of liabilities that can be financed by the existing contribution rate $\theta$, without periodic supplements from the sponsor, in a stationary state, is the product on the right hand side of Equation 1 (Settergren and Mikula, 2005):

$$
C A_{t}=\underbrace{C_{t}{ }^{*} \underbrace{f(\text { benefit parameters, } \gamma, g, d)}_{\text {T.D }}}_{\text {Contribution Asset }}
$$

with $C A_{t}$ being the value of the Contribution Asset. This result is inserted in the corresponding entry of the balance sheet. This method is valid for both defined-benefit and notional definedcontribution systems, because only steady states are being considered.

\section{The turnover duration (TD) ${ }^{6}$}

Consider the assumption that the economy within which the pension system operates is in a "golden-rule" stationary state, which is defined by the attribute that the real interest rate is equal to the real growth rate of the contribution base, which in turn is equal to the real growth rate of the economy. In a golden-rule stationary state, the interest or discount rate used to value both liabilities and assets is obtained directly from the growth rate of the economy G, avoiding any investigation of the financial market to identify the rate of interest applicable.

Appendix 1 determines the form of the function $f(\cdot)$ for the specific benefit formula used in Spain, if $\gamma=0$ and $\mathrm{d}=\mathrm{g}$. In this case, the value of this function is the well-known concept of "average pay-in and pay-out durations".

$$
d=g, \gamma=0 \Rightarrow f(\text { benefit parameters, } \gamma, g, d)=\left(p t_{r}+p t_{c}\right)
$$

with $p t_{c}$ being the pay-in duration of one monetary unit for any $\mathrm{g}$, and $p t_{r}$ being the pay-out duration of one monetary unit for any g. Appendix 1 also proves that the turnover duration simplifies even more, becoming the difference between the weighted average age of pensioners and the weighted average age of contributors (see figure 1).

$$
A_{r}-A_{c}=\left(A_{r}-\overline{\mathrm{R}}\right)+\left(\overline{\mathrm{R}}-A_{c}\right)=p t_{r}+p t_{c}
$$

with $\mathrm{A}_{c}$ being the average weighted age for the contributors (weighted by contribution sizes that take into account the age-earnings profile), $\mathrm{A}_{r}$ being the average weighted age for the

\footnotetext{
${ }^{6}$ Lee (1994) began the formal development of these formulae. See also the papers by Devesa et al. (2000, 2002) and Bravo (1996), who developed a concept in which a time average may, under certain conditions, represent the structure of salaries and pensions by age, like the difference between the average age of pensioners and contributors. Another pioneering paper which arrives at similar formulae is Arthur and McNicoll (1978).
} 
pensioners (weighted by pension sizes that take into account the age-benefits profile) and $\bar{R}$, the average weighted retirement age (weighted by initial pension size). Expression (4.) for TD remains valid for any constant $\gamma$ because the weights take into account the rate of fertility-driven population growth $(\gamma)$.

It can be interpreted that on average there will be TD years of annual contributions coming into the system before the pension commitments incurred this year have to be paid out as benefits. This is the economic intuition for the Contribution Asset ${ }^{7}$. A longer measured turnover duration thus implies that the system can finance higher pay-as-you-go benefits, and vice versa.

\section{FIGURE 1}

Turnover duration (TD). Adapted from Settergren (2003).

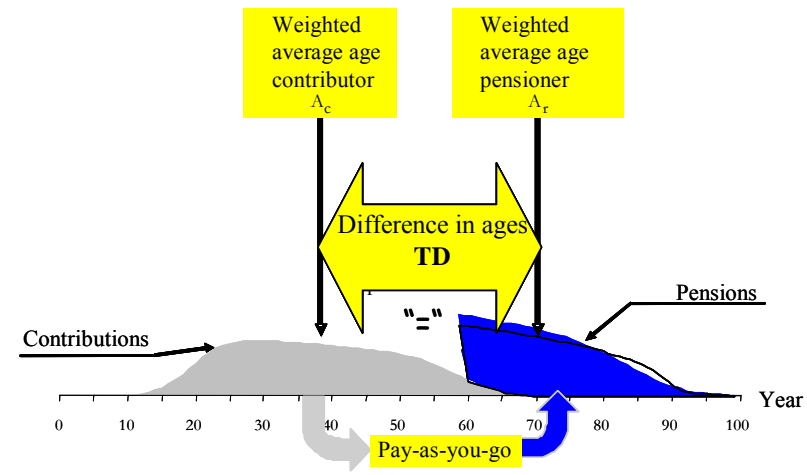

In 2006, Spain's expected turnover duration was 33.3, suggesting that the Spanish system can finance pension liabilities not larger than 33.3 times annual pension contributions. ${ }^{8}$

Appendix 1 also finds that the net effect of an increase in $g$ (an increase in the growth rate of average covered earnings in real terms) is to decrease the turnover duration.

$$
\left[\left(p t_{r}^{g>0}+p t_{c}^{g>0}\right)\right]<\left[\left(p t_{r}^{g=0}+p t_{c}^{g=0}\right)\right]
$$

Of course, the value of the liabilities when the discount rate $d$ equals $g(d=g)$ decreases in the same proportion as the Contribution Asset. The point of equation (5.) is that the number of effective years of contributions that will come into the system before the pension commitments incurred this year have to be paid out as benefits falls when $g>0$ is lower than when $g=0$.

\section{The Hidden Asset ${ }^{9}$}

According to Valdés-Prieto (2002), the Hidden Asset is the present expected value of the hidden taxes that the system will apply to its participants in the future, whether in the form of excess contributions in relation to the pensions to be provided or in the form of insufficient pensions in relation to the contributions. The Hidden Asset does not rely on a golden rule assumption, so the discount rate (d) is normally larger than the growth rate of GDP, and may be linked to interest rates in the financial markets.

The Hidden Asset (for the case of pure pay-as-you-go and two-period lives) is defined as:

$$
H A \equiv \sum_{i=0}^{\infty} \frac{T(t+i)}{(1+r)^{i}}=\frac{\frac{(y(t) \cdot N(t)) \beta \cdot(r-G)}{(1+G)(1+r)}}{1-\frac{(1+G)}{(1+r)}}=\underbrace{\frac{\beta \cdot y(t) \cdot N(t)}{1+G}}_{\text {Pensions paid to the first generation }}
$$

\footnotetext{
${ }^{7}$ See Lee (1994) p. 27.

${ }^{8}$ In 2006, the expected turnover duration for Sweden is 31.93. The evolution of the turnover duration in Spain in 2001-2006 is in Appendix 4, Table 7

${ }_{9}^{9}$ See Appendix 2 for more details.
} 
With $T(t+i)$ being the hidden taxes charged to each generation i of participants during their working period and $r$ being the real rate of interest (used as discount rate); $N(t)$ is the number of working participants ("young people") in period $t ; y(t)$ is pensionable earnings of the workers in $\mathrm{t} ; \beta$ is the replacement rate that the system pays in the second period of life; and $\mathrm{G}$ is the growth rate of the contribution base, the growth rate of aggregate flow of tax revenues from one generation to the next and also the growth rate of GDP.

Appendix 2 also shows that the Hidden Asset is equal to the pensions paid to the first generation (in the case of pure pay-as-you-go). This result was first obtained by Lüdecke (1988), and subsequently it has been shown by Sinn (1990, 2000), Geanakoplos et al. (1998), Valdés-Prieto (2002) and Lindbeck and Persson (2003).

If $r=G$, there is a question about the correct value of HA and the validity of equation (6.). It is difficult to interpret HA as the present value of taxes in the case $r=G$, because in this case the per-generation tax is zero. This is resolved by noting that HA is not a continuous function of $r$ at $r=G^{10}$.

First, the limit when $r$ approaches $G$ from below is minus infinity. The explanation is that in the case of $r<G$ each generation obtains a subsidy, and the value of the subsidy is unbounded because of the infinite horizon and a growth rate larger than the discount rate. Introducing payas-you-go finance creates wealth in a dynamically inefficient economy, which includes the cases $r<G$ and $r=G$. Second, consider the limit for HA when $r$ approaches $G$ from above. As $r$ falls towards $G$, the per-generation tax falls towards zero, but the tax revenue of the whole generation grows at rate $\mathrm{G}$ per period and that revenue is also discounted at a rate $r$ that becomes closer to G. If this second factor operated alone, it would push the present discounted value of the taxes paid by all generations towards infinity. When the two factors operate together, they cancel exactly. This explains the result of equation (6.) (also Appendix 2), which shows that HA is positive when $r$ tends to $G$ from above.

Thus, HA is positive in two cases: (i) when the economy is dynamically efficient ( $r>G$ ); and (ii) at the limit when $r$ approaches $\mathrm{G}$ from above. The value of HA at this limit is equal to the value of CA for the two-period life economy. The CA differs from the HA at $r=\mathrm{G}$, in the sense that the HA is undefined because it has two different limits, while the CA has a unique value.

The amount of the Hidden Asset also depends inversely on the amount of the sponsor's periodic contributions, if any. Consider first a situation in which both the pension system and the economy are stationary. When the amount of the sponsor's periodic contributions increases, with no changes being made to the size of the pensions, it will be possible to reduce the contribution rate applied to the participant. This will reduce the amount of hidden tax and the size of the Hidden Asset. In the balance sheet, the present value of the sponsor's periodic contributions appears as "Accumulated Deficit". Therefore, for pension payments of a fixed size (and therefore for fixed liabilities), any increase in the Accumulated Deficit is compensated for by an equal reduction in the Hidden Asset. The identity of the balance sheet is preserved.

If the amount of the sponsor's periodic contributions were to increase sufficiently, the Hidden Asset would become nil or even negative. This last situation would indicate that instead of a hidden tax there is a "hidden subsidy" in favour of participants in the form of contributions with a present discounted value lower than the present discounted value of the pension benefits to be obtained. In the situation with a negative Hidden Asset, the IRR obtained by each generation of participants in these stationary states is greater than the rate of interest offered by the financial market if the extra taxes are borne by others, different from the plan's participants.

Applying the Hidden Asset to compile the actuarial balance sheet has so far been theoretical. The infinite-horizon projection provided by the Board of Trustees of Social Security

\footnotetext{
${ }^{10}$ See Valdés-Prieto (2002) p. 437 on this aspect.
} 
in the United States is not explicitly based on the present value of hidden taxes (the Hidden Asset), but is equivalent to $i^{11}{ }^{11}$. In practice the problems of applying the Hidden Asset approach include the uncertainty about choosing a value for $\mathrm{r}^{12}$ (the real rate of interest for safe investments) and the need to assume something about economic and demographic trends.

\section{Entries on the liabilities side.}

This section examines the calculation of the liabilities contained in the balance sheet in more detail. In contrast to the previous section, this calculation takes into account real details of the benefit formula and current demographic and economic circumstances, both of which are usually much more complex than steady state assumptions. This, in turn, may be done with projections or using cross-section data. References and papers dealing with the calculation of actuarial liabilities are standard.

For commitments with pensioners, actuaries use the term "technical provisions for pensions in payment", the amount of which is labelled here as liabilities to pensioners. For contributors, actuaries use "technical provisions for rights being acquired", which will be reported as liabilities to contributors. Both have to be quantified following the standard procedures of actuarial mathematics.

For a balance sheet to make sense, the discount rate used for assets must be the same as the one used to determine liabilities, adjusting for risk. For this reason, the assumptions used to discount future pensions can differ notably according to whether it is the Contribution Asset being calculated, or if it is the Hidden Asset being calculated, or if it is a fully funded system being considered. In the first case the appropriate rate of discount is the growth rate of GDP (G), which coincides with the IRR paid by the pay-as-you-go system to each generation, under the assumptions mentioned. However, when the Hidden Asset is being calculated, the discount rate used for liabilities must be the expected return of safe investments.

The technical provisions for pensions in payment are the present value of the amount of all the pensions accrued until the date of the balance sheet. Again, the life table and other population data must be consistent with those used on the assets side for the balance sheet to make sense. As the Contribution Asset is calculated under the assumption of a stationary state, the population data in the cross-section are identical to those applicable to longitudinal projections, so cross-section data are equally as valid as longitudinal data. Cross-section data are normally used in this case. As the Hidden Asset does not assume a steady state, and is therefore based on longitudinal projections, the population data used to provision for pensions in payment in that case must also be longitudinal projections. In fully funded systems, this provision is the capital that would be needed to purchase in the financial market a guarantee that pensioners will be paid their recognised pensions.

Calculating the technical provisions of rights in the process of being acquired (liabilities to contributors) also requires consistency with the method used to value assets. In the case of notional defined contribution (NDC) systems that value assets using Contribution Asset methodology, this provision would simply be the notional capital present at each moment in the virtual accounts (formed by the contributions made by participants, plus the return deriving from the notional rate of interest credited to those accounts), provided that the notional interest rate credited to the virtual accounts is equal to the discount rate used to calculate the Contribution Asset. In the case of a fully funded system that values assets with financial prices, this provision would simply be the value of the financial capital in the participants' accounts.

In other cases the calculation is less simple. With defined benefits, for example, these technical provisions can be obtained by applying the prospective method (the difference between the present value of the insurer's future commitments and those of the contributor), or the retrospective method (the difference between the present value of the contributor's past commitments and those of the insurer). In an actuarially fair system in which perfect

\footnotetext{
${ }^{11}$ See BOT (2007), section IV.B.5.

${ }^{12}$ See the paper by Queisser and Whitehouse (2006) on this aspect.
} 
information were available because the system operated within an economic and demographic steady state, both methods would provide the same result. In practice they differ. When acquired rights are fully respected, the prospective method is applied.

\section{The Swedish experience with the actuarial balance sheet.}

The evolution of the actuarial balance sheet for the Swedish system during the period 20012006 is shown in Table 2. It is reviewed the construction of the different items, emphasising the solvency ratios rather than the size of items as compared to GDP.

\begin{tabular}{|c|c|c|c|c|c|c|}
\hline \multicolumn{7}{|c|}{$\begin{array}{c}\text { TABLE } 2 \\
\text { Balance sheet of the Swedish pension system at Dec. } 31 \text { of each year as \% of GPD. }\end{array}$} \\
\hline Year & 2006 & 2005 & 2004 & 2003 & 2002 & 2001 \\
\hline \multicolumn{7}{|c|}{ ASSETS } \\
\hline Financial Asset & 30.3 & 28.8 & 25.2 & 23.5 & 20.6 & 24.7 \\
\hline Contribution Asset & 209.9 & 214.2 & 218.6 & 222.2 & 223.2 & 222.2 \\
\hline Total Assets & 240.2 & 243.0 & 243.8 & 245.7 & 243.7 & 246.9 \\
\hline \multicolumn{7}{|c|}{ LIABILITIES } \\
\hline Liability to Contributors & 167.8 & 172.7 & 174.9 & 175.4 & 175.3 & 172.3 \\
\hline Liability to Pensioners & 68.9 & 69.2 & 68.5 & 67.9 & 66.3 & 65.1 \\
\hline Accumulated surplus & 1.0 & 0.3 & 2.3 & 2.1 & 9.2 & 9.5 \\
\hline Change in Net Worth & 2.5 & 0.7 & -1.9 & 0.3 & -7.0 & \\
\hline Total Liabilities & 240.2 & 243.0 & 243.8 & 245.7 & 243.7 & 246.9 \\
\hline \multicolumn{7}{|c|}{ FUNDING AND SOLVENCY INDICATORS } \\
\hline $\begin{array}{c}\text { Solvency ratio } \\
\text { (Total Assets/Liabilities) }\end{array}$ & 1.0149 & 1.0044 & 1.0014 & 1.0097 & 1.0090 & 1.0402 \\
\hline $\begin{array}{c}\text { (Degree of funding)\% } \\
\text { (Financial Asset/Liabilities) }\end{array}$ & 12.80 & 11.90 & 10.35 & 9.64 & 8.51 & 10.40 \\
\hline (Liabilities to Contributors/Liabilities)\% & 70.9 & 71.4 & 71.8 & 72.1 & 72.6 & 72.6 \\
\hline
\end{tabular}

The "Financial Asset" is the value of the financial assets owned by the Swedish pension system at the date of the balance sheet. Its valuation is made according to internationally accepted principles, i.e. based on the financial prices of the securities held.

The Contribution Asset is calculated in the way described in Försäkringskassan (2007), i.e. it is the annual contribution flow multiplied by turnover duration (TD). This turnover duration is based on population data obtained from a cross-section, not from a projection. Recall that this is valid on the assumption of a steady state for the economy, demography and the pension system. To limit fluctuation in the annual result of the pension system, the contribution flow used in the calculation of the contribution asset is smoothed.

The Liability to Contributors is calculated as the notional capital accumulated in the participants' accounts. Liabilities to contributors as a proportion of total liabilities amounted to $70.9 \%$ in 2006.

The Liability to Pensioners is the "nominal" value of benefits expected to be paid, considering the current number of survivors and thus implicitly the life table and other population data that are taken from a cross-section of the data observed in the last year. This calculation also takes into account that benefits are indexed in a specific way by current law.

The Accumulated Surplus is the "accumulated profit" or net worth of the pension system, which is owned by the system's sponsor, in this case the State. The system's annual profit or loss is the difference between the increase in assets and the increase in liabilities during that period. The loss is also identical to the increase in the Accumulated Deficit or the reduction in the Accumulated Surplus, depending on the situation. It is important not to confuse this profit or 
loss with the annual cash deficit or surplus. The Swedish authorities present a detailed results account in their annual report, showing the sources of changes in net worth.

Both the assets and liabilities are valued on the basis of verifiable cross-section facts, i.e. no projections are made. For example, current longevity is used even though it is expected to increase. If and when that expectation materialises in new mortality tables, this will be incorporated into the information on the balance sheet on a year-to-year basis. Because of this assumption, the calculation of the Contribution Asset does not take into account that contributions will grow in line with real salaries due to expected economic growth. The Swedish authorities note that the system's solvency ratio does not depend on the amount of the assets and liabilities separately, but on the relation between them via the solvency ratio, and for this reason, valuing the assets and liabilities with cross-section data is adequate if applied consistently.

In Sweden, the valuation of the flow of the system's contributions and liabilities is based almost exclusively on data observed at the date of valuation. This should not be interpreted as a belief that all the basic parameters determining the items on the balance sheet will remain constant in time, but as a result of a conscious policy to prefer cross-section data. Changes are not included until they happen and can be verified. Försäkringskassan (2002) argues that another advantage of using cross-section data is that it avoids the manipulations and biases that could affect any projections ${ }^{13}$.

Actually, long term projections of the system's possible future evolution are also included in the annual report of the Swedish pension system, with three basic scenarios being included normal, pessimistic and optimistic-. However, this information is not used in the preparation of the actuarial balance sheet, and is not used to make annual decisions or adjustments that may affect contributors and pensioners.

It is useful to remember that, in contrast to most defined-benefit systems, the design of the Swedish pension has a built-in direct relation between the long-term evolution of the system's assets and liabilities due to the use of notional accounts, with a notional interest rate which has been similar to the internal rate of return of the system.

If the solvency ratio is greater than one, the current Swedish system allows the assets and liabilities to evolve at slightly different rates. On the other hand, if the solvency ratio is less than one, then the Swedish system imposes an "automatic balance mechanism", which is a legislated formula that modifies the notional interest rate credited to contributions and the indexation rate for pensions, with the purpose of bringing assets closer to liabilities.

As can be seen in Table 2, the degree of funding of the Swedish system is clearly positive. This allows possible annual shortfalls in the system's income as compared to expenditure to be dealt with by selling financial assets. The high degree of solvency, on the other hand, implies that it is not likely that support from the sponsor (the State) will be sought.

The size of items in Table 3 as compared to GDP may depend on aspects of the design of the pension system, such as DB versus Notional DC and the type of pension indexation. To the extent that this is so, they are less relevant for international comparisons.

\footnotetext{
${ }^{13}$ This is one of the differences between the balance sheets in Sweden and the USA. The Board of Trustees for Social Security in the USA produces projections of demographic, economic and financial variables over both a 75-year period and an infinite horizon. In contrast, Sweden applies the principle of valuing based on facts verified at the date of the balance sheet, revealed by cross-section ratios. All in all it could be said that the Swedish and American balance sheets are complementary indicators; the projection method provides an idea of how the balance sheet may evolve in the future, whereas in the cross section method decisions are made according to a balance sheet which incorporates effective changes only, which may or may not coincide with those expected. In contrast, a projection approach would sometimes require the authorities to argue that pensions must decrease (in real terms) because the projection for economic growth worsened or because longevity is expected to increase.
} 


\section{The actuarial balance sheet for the Spanish pension system.}

This section shows the first estimates of the actuarial balance sheet for the Spanish contributory retirement pension system, with the aim of producing a solvency indicator for the system. At present many observers mistakenly take the annual cash-flow deficit/surplus to be a solvency indicator, despite the fact that it is only a liquidity indicator. It is not difficult to imagine situations in a pay-as-you-go pension system in which a series of annual cash-flow surpluses may come about at the same time that the system's insolvency ratio is increasing. The opposite situation could also be true. To evaluate whether or not the system is solvent, it is essential to compile a balance sheet.

The balance sheet for the Spanish pension system will include information relating to the commitments acquired with current workers and pensioners for the retirement contingency of the following social security regimes: general, agrarian workers (employed and self-employed), self-employed workers, coal mining, domestic employees, sea workers and the former Compulsory Old-Age and Permanent Disability Insurance (SOVI: Seguro Obligatorio de Vejez $e$ Invalidez). Due to lack of information, we will not include the regime for civil servants and public sector workers.

A balance sheet always assumes that the system is closed: there can be no new members, and members can only exit through death or permanent disability. The system's commitments to all current pensioners and workers are taken into account, always assuming that current legislation holds. In the case of liabilities to workers, the prospective method is used, so their future contributions are subtracted from their expected pension benefits.

The philosophy used to compile the balance sheet in Sweden will be followed as far as possible when valuing the Spanish system's assets and liabilities, i.e. the calculations will be based on verifiable facts observed at the date of the balance sheet, with the lowest possible number of projections. However, there are differences in the design of the system (DB versus Notional DC) and in the type of pension indexation that will lead us to significant deviations.

To provide sensitivity analysis for the solvency ratio $^{14}$, we also calculate the balance sheet for the cases $\mathrm{g}=\mathrm{d}=1.5 \%$ and $\mathrm{g}=\mathrm{d}=3 \%$. This is also useful to verify that the ratio of each balance sheet item to GDP falls as the discount rate and the projected growth rate of average real salaries rise. In all cases the turnover duration is calculated assuming a golden- rule steady state, so the discount rate is always set equal to the projected growth rate of average real salaries in that particular scenario.

The assets side will include the stock of financial assets (the reserve fund) and the Contribution Asset, which will be determined by the flow of contributions allocated to cover the retirement contingency for each regime, and the economic (amounts) and demographic characteristics of the groups of contributors and pensioners.

\section{Data.}

Data on the number of pensioners and amounts by contingency, regime, sex and age were obtained from the Spanish Social Security website and from information supplied by the Office of the Deputy Director of Economics at the National Institute of Social Security (Instituto Nacional de la Seguridad Social).

The information on participants registered as working, by regime and sex, and on registered retirement pensions by age was obtained from the Annual Reports of Employment Statistics and Social Affairs for 2006, 2005, 2004, 2003, 2002 and 2001.

Data on the total amounts of contributions by regime are shown in the economic-financial report on Social Security budgets for 2008.

Data on the average contribution bases, by regime and age, have been estimated based on "Microdata from the Continuous Sample of Working Lives 2005" (Microdatos de la Muestra

\footnotetext{
${ }^{14}$ See Appendix 3.
} 
Continua de Vidas Laborales) supplied by the Ministry of Labour and Social Affairs (MTAS). For example, for the General Regime of Social Security, work was carried out using a sample of over 600,000 individuals for each of the years that estimates have been made for the balance sheet (2001-2006).

A summary of the data and the most relevant variables for calculating the balance sheet is provided in Appendix 4.

\section{Other assumptions.}

It is assumed that individuals join the labour market at age 25, except those who are already in the system at an earlier age, and contribute throughout their working lives with $100 \%$ density.

The mortality tables used are those from the National Institute of Statistics (Instituto Nacional de Estadística) 98-99. The permanent disability tables are those drawn up by Vicente et al. (2003) using data from Spanish Social Security. Although only the retirement contingency is evaluated, it should not be forgotten that current workers might not receive their retirement pension for two possible reasons: death or permanent disability. Therefore, to avoid overvaluing liabilities to contributors, multiple decrement life tables need to be used. These tables are compiled by combining those from the NIS 98-99 and the permanent disability tables drawn up by Vicente et al. (2003).

The real technical interest rate applied to discount future pensions and contributions is the IRR of the pay-as-you-go system. To be consistent with the estimate of the Contribution Asset (stationary state with population stability and salaries constant in real terms), this rate has to be $0 \%$. It should be noted, see Appendices 1 and 3, that the system's financial position does not depend on the amount of assets and liabilities separately, but on the relation between them expressed by the solvency ratio.

In the Spanish social security system, the total contributions for common contingencies have no specific allocation to each contingency. The allocation of income from contributions applicable to the retirement contingency is calculated by taking into account the percentage represented by expenditure on pensions, for each contingency, out of the total expenditure for common contingencies.

The expenditure on pensions caused by the supplement to the minimum retirement benefits ${ }^{15}$ is considered income from contributions.

It is assumed that the pensions drawn by each beneficiary remain constant in real terms, as do the minimum and maximum pensions for each year of reference.

Salaries (contribution bases) are kept constant in real terms for each age group, which implies supposing that contributors will obtain wage rises only for increases in age.

It is considered that individuals can retire at age $60,61,62,63,64$ and 66 . The probability that they will retire at one of these ages is calculated from the pension applications by age for the year of reference. The retirement age for individuals of 62 is considered to be equal to 66 , and for those of 67 equal to 70 . Individuals of 67 do not pay contributions at 68 and 69, but, following Law 35/2002, for the calculation of their pension base it is as if they had contributed.

The pension base is calculated by taking into account the 15 years before retirement age, as required by the current benefit formula. The first pension to which pensioners will be entitled is equal to $100 \%$ of the pension base; with a $7 \%$ reduction being applied for each year that retirement is brought forward from age 65 . On the other hand, the pension base for individuals of 67 , who will retire at 70 , will be multiplied by 1.1 . ( $2 \%$ more for each year that retirement age is delayed beyond age 65).

\footnotetext{
${ }^{15}$ The necessary supplements that allow the pension to reach the amount called minimum pension.
} 


\section{Results for Spain.}

The evolution of the balance sheet for the Spanish system for the period 2001-2006 is shown in Table 3.

Regarding the entries on the assets side, in the Spanish case (2001-2006):

The value of the Financial Asset has grown steadily since 2001, rising from $0.36 \%$ to $3.68 \%$ of GDP. This is due to the fact that the contributory system showed a cash-flow surplus and it was used to build up a reserve fund. The balance sheet shows, (see line Contributions/Benefits), that under the supposition that all the supplements for minimum pensions are financed by the State, there has been a cash surplus for contributory retirement over the last few years. Its size has varied between 13.84\% (2006) and 10.75\% (2005) of GDP. Nevertheless, the degree of funding of the Spanish system remains low, barely reaching $1.29 \%$ of liabilities in 2006 (in Sweden the degree of funding was $12.80 \%$ in 2006).

\begin{tabular}{|c|c|c|c|c|c|c|}
\hline \multicolumn{7}{|c|}{$\begin{array}{c}\text { TABLE } 3 \\
\text { Balance sheet at Dec. } 31 \text { of each year for the Spanish pension system as \% of GPD. Consolidated for all } \\
\text { regimes. }\end{array}$} \\
\hline Year & 2006 & 2005 & 2004 & 2003 & 2002 & 2001 \\
\hline \multicolumn{7}{|c|}{ ASSETS } \\
\hline Financial Asset & 3.68 & 3.00 & 2.30 & 1.54 & 0.85 & 0.36 \\
\hline Contribution Asset & 192.21 & 189.18 & 189.25 & 194.73 & 196.85 & 204.49 \\
\hline Accumulated Deficit & 85.46 & 88.72 & 79.30 & 76.58 & 67.17 & 71.96 \\
\hline "Losses for the period" & 4.12 & 3.42 & 16.32 & 8.55 & 15.01 & 0.00 \\
\hline Total Assets & 285.47 & 284.32 & 287.17 & 281.40 & 279.88 & 276.81 \\
\hline \multicolumn{7}{|c|}{ LIABILITIES } \\
\hline Liability to Pensioners & 60.01 & 60.82 & 60.76 & 61.63 & 63.31 & 62.11 \\
\hline Liability to Contributors & 225.45 & 223.49 & 226.41 & 219.77 & 216.56 & 214.70 \\
\hline Total Liabilities & 285.47 & 284.32 & 287.17 & 281.40 & 279.88 & 276.81 \\
\hline \multicolumn{7}{|c|}{ FUNDING, SOLVENCY AND LIQUIDITY INDICATORS } \\
\hline Ratio of (in)solvency & 0.686 & 0.676 & 0.667 & 0.697 & 0.706 & 0.740 \\
\hline (Degree of funding)\% & 1.29 & 1.06 & 0.80 & 0.55 & 0.30 & 0.13 \\
\hline (Liabilities to Contrib./Liabilities)\% & 79.0 & 78.61 & 78.84 & 78.10 & 77.38 & 77.56 \\
\hline (Contributions/Benefits) annual\% ${ }^{16}$ & 113.84 & 110.75 & 111.27 & 113.09 & 111.78 & 111.78 \\
\hline
\end{tabular}

The value of the Contribution Asset is smaller in Spain than in Sweden, relative to GDP: about $192 \%$ of GDP in Spain, as compared to $210 \%$ for Sweden. The evolution of the Contribution Asset in Spain is rather worrying: it has fallen by 12 percentage points of GDP in barely 5 years, from $204.49 \%$ to $192.21 \%$ of GDP. In Sweden the fall has been 8.2 percentage points of GDP. Proportionally the worst falls in Spain have occurred in the coal mining and agrarian worker regimes, as can be seen in Appendix 4.

The tables in Appendix 4 show that the fall in the Contribution Asset as a proportion of GDP is due to two basic reasons:

a) Ageing of contributors has decreased the Turnover Duration, i.e. the difference between the weighted average age of the pensioners and the contributors. In the case of the general regime, the most important one, this decrease can be assessed at approximately 0.92 years (34.01-33.09). All the regimes, except the one for domestic employees, experience this process.

b) The rhythm of growth of contribution revenue has been slower than GDP growth. This is clear for the two most important regimes (general and self-employed workers). Contribution revenue has actually stagnated or fallen in the regimes for sea workers, coal mining and agrarian workers. The exception again is the regime for domestic workers. All this has come about in the context of a large increase in participants in three regimes in 2005; the general, the self-

\footnotetext{
${ }^{16}$ This includes the supplement to minimum retirement benefits.
} 
employed worker and, especially in the domestic employee regimes. Thus, the average contribution per participant in real terms has decreased in the general and domestic employee regimes, although it has grown in the others.

On the liabilities side, Table 3 shows that in Spain:

a) The liability with retirement pensioners decreased by $2.09 \%$ of GDP in the period 20012006. This fall has not been uniform. Indeed, some regimes have increased the value of their liability with retirement pensioners in relation to GDP: the general regime by $0.29 \%$ and the SOVI by more than $15 \%$. The biggest decreases occurred in the self-employed agrarian worker regime (-21.87\%), domestic employees $(-22.16 \%)$ and coal mining $(-15.09 \%)$.

b) The share of commitments to contributors for retirement within total liabilities is $79 \%$, which is 9.1 percentage points higher than in Sweden. These commitments increased by $10.75 \%$ of GDP in 2001-06, with the biggest increases occurring in those regimes that have grown in number of contributors: self-employed workers and domestic employees.

An important question is whether the solvency ratio is constant across different scenarios. The sensitivity analysis (Appendix 3 ) shows that the solvency ratio remains almost the same for two alternative scenarios. This constancy does not extend to the other two ratios reported in Table 4. The funding ratio doubles when the discount rate and the growth of average salaries rise from $0 \%$ to $3 \%$. The reason is that financial assets are always reported at their current market value in all scenarios, while total liabilities fall very significantly. The ratio of liability to contributors to total liabilities also falls, but not as strongly as the funding ratio, when the discount rate and the growth of average salaries rise from $0 \%$ to $3 \%$. The reason is that because liabilities to contributors are farther away in the future, they fall faster than the liability to pensioners.

The size of total liabilities is $285.47 \%$ of GDP in Spain, which is about 48.77 percentage points bigger than the comparable value for Sweden. This difference is due to a combination of factors, among which the following stand out: the different age structure, the difference in contribution density trajectories, the difference in retirement patterns and the difference in generosity. The latter includes differences in retirement ages, replacement rates and pension indexation rules, and can be identified by the excess of the IRR over the growth rate of the contribution base.

The liabilities reported by the balance sheets in Table 3 should not be confused with the cost of transferring the obligation to pay the commitments to a $100 \%$-capitalised insurance company, or to a fully funded pension system. The cost of fully funding the liabilities would be less than that indicated by these balance sheets because, in order to carry out the calculations leading to Table 4 , it was supposed that the real discount rate is $0 \%$, while in a fully funded system the discount rate would have a positive value (1.5\%-3\%). However, as already indicated, the level of the discount rate affects the solvency ratio, i.e. the relation between the pension system's assets and liabilities, only very slightly, because both the liabilities and the Contribution Asset change in almost the same proportion in response to changes in the discount rate.

The evolution of the total assets, liabilities and accumulated deficit

Figure 2 shows the evolution of the assets, liabilities and accumulated deficit (as \% of GDP) along with the rates of variation for the same period. 
FIGURE 2

Evolution of the total assets, liabilities and accumulated deficit of the Spanish pension system and their rates of variation. Period 2001-2006.
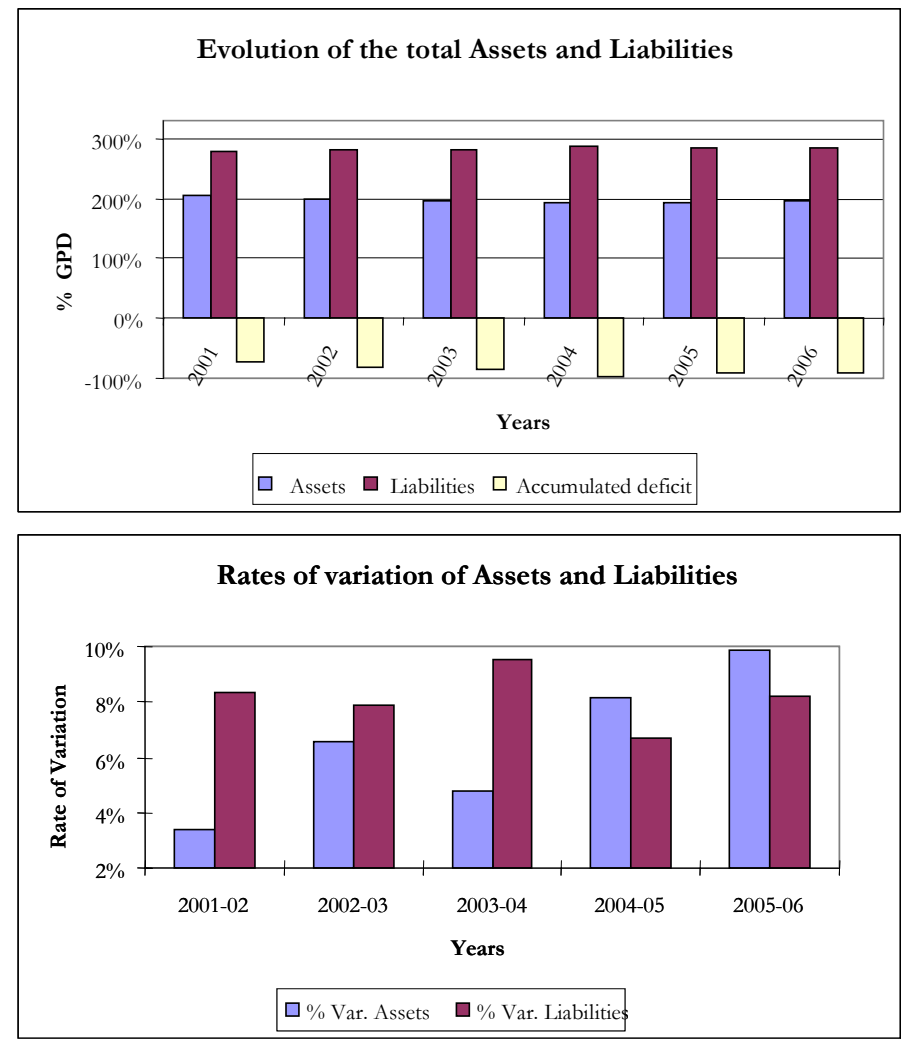

It can be appreciated that the assets and liabilities have evolved at very different rhythms (rates of variation). For the period under analysis, except for the last two years, the liabilities grew at a higher cumulative rate than the assets. In other words the system is not only insolvent given that liabilities exceed assets by $31.4 \%$, but it is also suffering a year-on-year increase in the degree of insolvency, although this appears to have stabilised over the last two years. Attaining solvency would only be possible if the liabilities grew at lower rates than the assets, which is exactly the opposite of what has been happening on average over the last six years.

Although the solvency of the system as a whole improved slightly in 2006, there is a deficit of $31.4 \%$ of liabilities. Contrary to some official signals of optimism as to the contributory pension system's financial health, the balance sheet shows a notable actuarial imbalance which calls for immediate reform.

By comparing Tables 2 (Sweden) and 3 (Spain) one can see the difference between a solvent system (Sweden), which backs up all its liabilities, and an insolvent one (Spain), which backs up only $68.6 \%$ of its liabilities. There is also a clear difference between a balanced system (Sweden), in which the rates of variation of the assets and liabilities are similar due to the fact that new participants do not bring any additional deficit with them, and an imbalanced system (Spain), in which the new participants increase the pension system's deficit. Because of this, the level of insolvency in Spain increases as the number of contributors increases.

\section{Balance sheets by pension regime}

Tables $4 \mathrm{~A}$ and $4 \mathrm{~B}$ show the balance sheet by regime, under the assumption that existing financial assets are distributed in proportion to the Contribution Asset of those regimes that have an annual cash surplus (the general and self-employed regimes). 


\begin{tabular}{|c|c|c|c|c|c|c|}
\hline \multicolumn{7}{|c|}{$\begin{array}{l}\text { TABLE 4A } \\
\text { Balance sheet for the Spanish pension system for the period 2001-2006 as \% of GPD at 31-12 each year. } \\
\text { By regime. }\end{array}$} \\
\hline Year & 2006 & 2005 & 2004 & 2003 & 2002 & 2001 \\
\hline \multicolumn{7}{|c|}{ ASSETS (General) } \\
\hline Financial Asset & 3.26 & 2.66 & 2.04 & 1.37 & 0.75 & 0.32 \\
\hline Contribution Asset & 162.64 & 159.80 & 159.73 & 164.64 & 165.89 & 171.48 \\
\hline Accumulated deficit & 64.05 & 66.03 & 69.41 & 59.81 & 57.71 & 48.84 \\
\hline Total Assets & 229.95 & 228.50 & 231.18 & 225.82 & 224.36 & 220.64 \\
\hline \multicolumn{7}{|c|}{ LIABILITIES (General) } \\
\hline Liability to Pensioners & 42.93 & 43.14 & 43.10 & 43.32 & 44.16 & 42.80 \\
\hline Liability to Contributors & 187.02 & 185.35 & 188.07 & 182.50 & 180.19 & 177.83 \\
\hline Total Liabilities & 229.95 & 228.50 & 231.18 & 225.82 & 224.36 & 220.64 \\
\hline (In)solvency ratio & 0.721 & 0.711 & 0.700 & 0.735 & 0.743 & 0.779 \\
\hline ((Contributions/Benefits) annual\% & 136.28 & 133.32 & 133.64 & 137.28 & 136.50 & 137.80 \\
\hline \multicolumn{7}{|c|}{ ASSETS ( Self-employed workers) } \\
\hline Financial Asset & 0.41 & 0.34 & 0.26 & 0.17 & 0.09 & 0.04 \\
\hline Contribution Asset & 20.20 & 20.28 & 20.62 & 20.37 & 20.76 & 21.92 \\
\hline Accumulated deficit & 11.93 & 11.74 & 11.2 & 10.14 & 8.58 & 7.12 \\
\hline Total Assets & 32.54 & 32.36 & 32.08 & 30.68 & 29.44 & 29.08 \\
\hline \multicolumn{7}{|c|}{ LIABILITIES (Self-employed worker) } \\
\hline Liability to Pensioners & 5.40 & 5.39 & 5.28 & 5.29 & 5.35 & 5.48 \\
\hline Liability to Contributors & 27.14 & 26.97 & 26.79 & 25.38 & 24.08 & 23.60 \\
\hline Total Liabilities & 32.54 & 32.36 & 32.08 & 30.68 & 29.44 & 29.08 \\
\hline (In)solvency ratio & 0.633 & 0.637 & 0.651 & 0.670 & 0.708 & 0.755 \\
\hline (Contributions/Benefits) annual\% & 141.28 & 141.78 & 145.75 & 144.24 & 144.04 & 138.39 \\
\hline \multicolumn{7}{|c|}{ ASSETS (Agrarian workers) } \\
\hline Financial Asset & 0.00 & 0.00 & 0.00 & 0.00 & 0.00 & 0.00 \\
\hline Contribution Asset & 6.17 & 6.25 & 6.57 & 7.18 & 7.55 & 8.34 \\
\hline Accumulated deficit & 8.03 & 8.43 & 9.29 & 9.43 & 9.93 & 10.22 \\
\hline Total Assets & 14.20 & 14.68 & 15.86 & 16.61 & 17.48 & 18.56 \\
\hline \multicolumn{7}{|c|}{ LIABILITIES (Agrarian workers) } \\
\hline Liability to Pensioners & 6.15 & 6.54 & 6.84 & 7.25 & 7.79 & 7.87 \\
\hline Liability to Contributors & 8.05 & 8.14 & 9.03 & 9.36 & 9.70 & 10.69 \\
\hline Total Liabilities & 14.20 & 14.68 & 15.86 & 16.61 & 17.48 & 18.56 \\
\hline (In)solvency ratio & 0.434 & 0.426 & 0.414 & 0.432 & 0.432 & 0.449 \\
\hline (Contributions/Benefits) annual\% & 29.87 & 28.62 & 28.95 & 29.96 & 29.97 & 31.12 \\
\hline
\end{tabular}

It can be seen that the general and self-employed regimes are in a situation of insolvency similar to the aggregate, although the accumulated deficit in terms of GDP has grown noticeably in the last five years.

This accumulated deficit contrasts with the comfortable situation of liquidity, expressed by the annual contributions/annual benefits ratio. In the last six years income has exceeded spending on retirement benefits in the general regime by $35 \%$ and in the self-employed regime by over $40 \%$.

The regime for self-employed workers is third, after the domestic employees, to the general regime as regards the degree of solvency. It has assets that cover only $63.3 \%$ of the commitments acquired with contributors and pensioners. Its situation has worsened over the last five years. 


\begin{tabular}{|c|c|c|c|c|c|c|}
\hline \multicolumn{7}{|c|}{$\begin{array}{l}\text { TABLE 4B } \\
\text { Balance sheet for the Spanish pension system for the period 2001-2006 as \% of GPD at 31-12 each year. } \\
\text { By regime (continuation). }\end{array}$} \\
\hline Year & 2006 & 2005 & 2004 & 2003 & 2002 & 2001 \\
\hline \multicolumn{7}{|c|}{ ASSETS (Domestic employees) } \\
\hline Financial Asset & 0.00 & 0.00 & 0.00 & 0.00 & 0.00 & 0.00 \\
\hline Contribution Asset & 2.35 & 1.95 & 1.37 & 1.49 & 1.49 & 1.47 \\
\hline Accumulated deficit & 1.03 & 1.25 & 1.26 & 1.23 & 1.29 & 1.23 \\
\hline Total Assets & 3.38 & 3.20 & 2.62 & 2.72 & 2.79 & 2.71 \\
\hline \multicolumn{7}{|c|}{ LIABILITIES (Domestic employees) } \\
\hline Liability to Pensioners & 1.13 & 1.20 & 1.26 & 1.33 & 1.43 & 1.45 \\
\hline Liability to Contributors & 2.25 & 2.00 & 1.37 & 1.39 & 1.36 & 1.26 \\
\hline Total Liabilities & 3.38 & 3.20 & 2.62 & 2.72 & 2.79 & 2.71 \\
\hline (In)solvency ratio & 0.694 & 0.608 & 0.522 & 0.549 & 0.535 & 0.544 \\
\hline (Contributions/Benefits) annual\% & 62.04 & 49.93 & 37.60 & 38.95 & 36.76 & 35.20 \\
\hline \multicolumn{7}{|c|}{ ASSETS (Sea workers) } \\
\hline Financial Asset & 0.00 & 0.00 & 0.00 & 0.00 & 0.00 & 0.00 \\
\hline Contribution Asset & 0.66 & 0.67 & 0.69 & 0.71 & 0.77 & 0.83 \\
\hline Accumulated deficit & 1.40 & 1.49 & 1.57 & 1.53 & 1.59 & 1.54 \\
\hline Total Assets & 2.07 & 2.16 & 2.26 & 2.25 & 2.36 & 2.37 \\
\hline \multicolumn{7}{|c|}{ LIABILITIES (Sea workers) } \\
\hline Liability to Pensioners & 1.28 & 1.32 & 1.36 & 1.40 & 1.45 & 1.42 \\
\hline Liability to Contributors & 0.79 & 0.83 & 0.90 & 0.85 & 0.92 & 0.95 \\
\hline Total Liabilities & 2.07 & 2.16 & 2.26 & 2.25 & 2.36 & 2.37 \\
\hline (In)solvency ratio & 0.320 & 0.309 & 0.305 & 0.317 & 0.327 & 0.351 \\
\hline (Contributions/Benefits) annual\% & 26.13 & 25.70 & 26.22 & 26.20 & 27.73 & 28.57 \\
\hline \multicolumn{7}{|c|}{ ASSETS (Coal Mining) } \\
\hline Financial Asset & 0.00 & 0.00 & 0.00 & 0.00 & 0.00 & 0.00 \\
\hline Contribution Asset & 0.20 & 0.23 & 0.28 & 0.33 & 0.38 & 0.45 \\
\hline Accumulated deficit & 1.18 & 1.21 & 1.27 & 1.31 & 1.33 & 1.31 \\
\hline Total Assets & 1.38 & 1.44 & 1.55 & 1.63 & 1.71 & 1.76 \\
\hline \multicolumn{7}{|c|}{ LIABILITIES (Coal Mining) } \\
\hline Liability to Pensioners & 1.18 & 1.24 & 1.29 & 1.34 & 1.40 & 1.40 \\
\hline Liability to Contributors & 0.20 & 0.20 & 0.25 & 0.29 & 0.31 & 0.37 \\
\hline Total Liabilities & 1.38 & 1.44 & 1.55 & 1.63 & 1.71 & 1.76 \\
\hline (In)solvency ratio & 0.147 & 0.162 & 0.179 & 0.201 & 0.224 & 0.253 \\
\hline (Contributions/Benefits) annual\% & 7.70 & 8.42 & 9.75 & 11.13 & 12.48 & 13.86 \\
\hline
\end{tabular}

The third regime by size of accumulated deficit is the one for agrarian workers. The absolute value of this deficit shows a downward trend over time due to the fact that the number of both contributors and pensioners is decreasing. Its solvency ratio is very low, with barely $43.4 \%$ of acquired commitments covered.

Special mention should be made of the Regime for Domestic Employees, the only one that has improved in terms of solvency as a result of the extraordinary increase in contributors over the last year. Despite this, the solvency ratio barely reached $69.4 \%$ at the end of 2006 .

The other special regimes (sea workers and coal mining) are of little quantitative importance but show a very high degree of insolvency. 


\section{The causes of insolvency in the Spanish case}

How has this situation come about? Why, in spite of an increase in contributors as a whole, does the Spanish system notch up "losses" every tax year? The answer that flows from these results is that the Spanish system suffers from a structural imbalance: the relation between the expected contributions and expected benefits "yields" too high an implicit IRR for the contributor. This is also true for new participants, suggesting that the implicit IRR is incompatible with the return that the system can pay out (which is the rate of contribution growth).

This problem has been described by the economics literature in the last few years ${ }^{17}$. DevesaCarpio et al. (2002) show that the real IRR obtained by contributors in the general regime, under normal conditions, is $4.26 \%$, which is way above the real historical growth of Spanish GDP (3\%) for the period 1970-2000 which they suggest as benchmark. This suggests that the system is financially unviable in the Samuelson-Aaron sense under the parameters currently in force. Of course it is possible to carry out a gradual adjustment of the parameters, but this adjustment would have to be big to eliminate the insolvency.

Devesa-Carpio and Vidal-Meliá (2004) confirm this conclusion using a different method. They find that the value calculated for the IRR according to the rules for 2003 in Spain is far above the other values obtained by retrospectively applying the rules for different countries which have adopted notional account systems. The result that stands out is that with these rules it would not have been possible to obtain an IRR above $3.6 \%$, the value of the average growth of GDP in Spain over the last 40 years (1964-2003).

The design of the pension system also has implications. In the Spanish defined-benefit design, the current evolution will continue until new legislation is adopted. In contrast, if the Swedish system had a balance sheet like the Spanish one, the automatic balance mechanism would be activated immediately. This would reduce the notional interest rate, cutting liabilities to contributors, and would also reduce the rate of indexation of pensions, reducing liabilities to pensioners. Specifically, the indexation rate of pensions and the notional interest rate received by contributors would be reduced by the percentage of insolvency, which is $31.4 \%$. This harsh adjustment would be maintained automatically until the balance sheet reached solvency.

Restoring solvency to the Spanish system would demand a legislative package of measures to reduce the growth of liabilities. The most immediate objective of public policy should be to stop the pension system accumulating "losses" year after year, i.e. it should recover actuarial equilibrium to prevent the insolvency from growing.

\section{Concluding Comments.}

The existence of the Contribution Asset shows that there is no basis for the arguments put forward by those who discredit pure and partial pay-as-you-go finance systems by saying that they are always "bankrupt" or insolvent. These arguments are based on observing the liabilities of the system while ignoring the assets (contribution asset, hidden asset) associated with the pay-as-you-go financing method. A balance sheet that includes these assets, such as the one reported in this paper, cannot be accused of trying to discredit pay-as-you-go finance.

This paper has clarified the relation between the Contribution Asset and the Hidden Asset concepts that are fundamental to enable the balance sheet for pay-as-you-go systems to be compiled with rigour- which establishes a correct indicator of the system's solvency. Some politicians, researchers and public opinion mistakenly consider the annual cash-flow deficit or surplus as an indicator of the pay-as-you-go system's solvency; i.e. they confuse a liquidity indicator with a solvency indicator. In order to assess whether or not a system is solvent, a balance sheet must be compiled.

\footnotetext{
${ }^{17}$ See the papers by Devesa-Carpio et al. (2000) and (2002), Devesa-Carpio and Vidal-Meliá (2004), Vidal-Meliá and DomínguezFabián (2006), Vidal-Meliá et al. (2006), Boado-Penas et al. (2007) and Alonso (2007) among others.
} 
The balance sheet for the Spanish pension system is a novelty since there is only one country -Sweden since 2001- which presents it periodically.

The main conclusion is that the balance sheet for the Spanish contributory retirement pension system as of 2006 shows a weak position of solvency. It also shows falls in the net worth of the system year after year. Although the solvency of the system as a whole improved very slightly in 2006 , the assets deficit was $31.4 \%$ of liabilities.

The Spanish system shows signs of a structural actuarial imbalance: the relation between the expected contributions and pension benefits "yields" too high an implicit IRR for the average participant, to such an extent that this implicit IRR is incompatible with the sustainable return of the system (which is the growth rate of real contribution revenue). Put another way, the cost of selling (pensions and acquired commitments with contributors) is much higher than the selling price (contributions). However, as the cost of selling will create cash flow deficits far off in time and the selling price manifests itself through immediate income, the paradox comes about that the more sold, the more positive the net cash flow observed over the recent years, but the greater is the degree of insolvency of the system as a whole.

The absence of a balance sheet in this specific case produces a "mirage effect". By hiding the presence of a capital deficit, it reduces the importance of future cash deficits because there is still time before they occur and still time meanwhile for "something to save the system".

Contrary to official optimism regarding the financial health of the contributory pension system in Spain, the results presented here show that adopting measures to restore solvency is urgent. The first measure should be to change the benefit formula to eliminate the "losses" or increases in the accumulated deficit, which accrue every year that goes by without reform.

\section{References}

Aaron H. (1966). "The Social Insurance Paradox", Canadian Journal of Economics and Political Science, XXXII, 3 (August). 371-4.

Alonso, J. (2007). "La contributividad y el desequilibrio actuarial de las pensiones de jubilación en España”, Panorama social, 4, 76-87.

Arthur, B. and G. McNicoll (1978). "Samuelson, population and intergenerational transfers" International Economic Review. (19) 1. 241-246.

Besley, T. and A Prat (2005). "Credible Pensions” Fiscal Studies 26 (1), 119-135

Boado-Penas, C, I. Domínguez-Fabián and C. Vidal-Meliá (2007). "Notional Defined Contribution Accounts (Ndcs): Solvency and Risk; Application to the Case of Spain" International Social Security Review, 60 (4), 105-127.

BOT, Board of Trustees, Federal Old-Age and Survivors Insurance and Disability Insurance Trust Funds (2007). 2007 Annual Report. Washington, D.C.

Boeri, T., A. Börsch-Supan. and G. Tabellini (2001). "Would you like to shrink the Welfare State? The opinions of European citizens", Economic Policy, 32, 9-50.

Bravo, J, (1996). "La tasa de retorno de los sistemas de pensiones de reparto" Estudios de Economía, (23) 1, Departamento de Economía. Universidad de Chile, Santiago.

Cigno, A. (2006). “Is there a Social Security Tax Wedge?” Cesifo. WP. 1772.

Devesa-Carpio, J. E., A. Lejárraga-García and C. Vidal-Meliá (2002). "El tanto de rendimiento del sistema de pensiones de reparto" Revista de Economía Aplicada, 30 (X), 109-132.

Devesa-Carpio, J. E., A. Lejárraga-García and C. Vidal-Meliá (2000). "The Internal Rate of Return of the Pay-As-You-Go System: An Analysis of the Spanish Case" Centre for Pensions and Social Insurance. Research Report 33/2000 Birkbeck College and City University of London. 
Devesa-Carpio, J.E. and C. Vidal-Meliá (2004). "Notional Defined Contributions Accounts (ndc's). What effect would they have had on the Spanish pension system?" Moneda $y$ Crédito, 219, 61-103.

Diamond, P. (1994). “Insulation of Pensions from Political Risk.” NBER WP-4895.

Disney, R.F. (2004). "Are contributions to public pension programmes a tax on employment?" Economic Policy, 19 (39), 267-311.

Geanakoplos, J, O. S. Mitchell, and S. Zeldes (1998). "Would a Privatized Social Security System Really Pay a Higher Rate of Return?" In Framing the Social Security Debate. Eds. D. Arnold, M. Graetz, and A. Munnell. Brookings Institution, 137-156.

Gronchi, S., and S. Nisticò. (2003). "Sistemi a ripartizione equi e sostenibili: medelli teorici e realizzazioni pratiche." CNEL-Documenti, N. 27.

Gronchi S. and Nisticò S. (2007). "Theoretical Foundations of Pay-as-You-Go DefinedContribution Pension Schemes" Metroeconomica, Forthcoming.

Holzmann, R., R. Palacios and A. Zviniene (2004). "Implicit Pension Debt: Issues, Measurement and Scope in International Perspective" 0403, Social Protection Discussion Paper Series. The World Bank. Washington D.C.

Lee, R. (1994). "The Formal Demography of Population Aging, Transfers, and the Economic Life Cycle" in Demography of Aging, edited by Linda G. Martin and Samuel H. Preston, National Academy Press. Washington, D.C.

Lindbeck, A. and M. Persson (2003). "The Gains from Pension Reform” Journal of Economic Literature, Vol. XLI (March), 74-112.

Lüdecke, R. (1988). "Staatsverschuldung, intergenerative redistribution und umlagefinanzierte gesetzliche Rentenversicherung: Eine andere sicht der lasten durch ein negatives bevölkerungswachstum", in J. Kalus and P. Klemmer (eds.) Wirtschaftliche Strukturproblemeund Soziale Fragen: Analysen und Gestaltungsaufgaben, Berlin: Duncker \& Humblot.

Ministerio de Trabajo y Asuntos Sociales (2006). Informe Económico Financiero a los Presupuestos de la Seguridad Social de 2007. Secretaría de Estado de la Seguridad Social, Dirección General de Ordenación de la Seguridad Social. Madrid.

Queisser, M. and E. Whitehouse (2006). "Neutral or Fair?: Actuarial Concepts and PensionSystem Design", OECD Social Employment and Migration Working Papers, No. 40, OECD Publishing

Samuelson P. (1958). "An Exact Consumption Loan Model of Interest with or without the Social Contrivance of Money', Journal of Political Economy, (68) 6, 467-82.

Seguridad Social MCVL_2005 (2007). Microdatos de la Muestra Continua de Vidas Laborales. Ministerio de Trabajo y Asuntos Sociales. CD.

Settergren, O (2001). "The Automatic Balance Mechanism of the Swedish Pension System - a non-technical introduction". Wirtschaftspolitische Blätter 4/2001, 339-349.

Settergren, O (2003). "Financial and Inter-Generational Balance? An Introduction to How the Swedish Pension System Manages Conflicting Ambitions." Scandinavian Insurance Quarterly 2, 99-114.

Settergren, O. and B.D. Mikula (2005). "The rate of return of pay-as-you-go pension systems: a more exact consumption-loan model of interest" The Journal of Pensions Economics and Finance, 4 (2), 115-138

Sinn, H.-W. (1990). Korreferat zum Referat von K. Jaeger, in B. Gahlen, H. Hesse and H. J. Ramser (eds.), Theorie und Politik der Sozialversicherung, Tübingen: Mohr-Siebeck, 99101 
Sinn, H.W. (2000). "Why a funded pension is useful and why it is not" International Tax and Public Finance 7, 389-410.

Takayama, N. (2005). "The balance sheet of social security pensions in Japan”, Proceedings No. 6, "The Balance Sheet of Social Security Pensions", Institute of Economic Research, Hitotsubashi University, February, 2005.

The Swedish Pension System Annual Report 2001. (2002). Ed. Ole Settergren, National Social Insurance Board (Försäkringskassan), Stockholm.

The Swedish Pension System Annual Report 2002. (2003). Ed. Ole Settergren, National Social Insurance Board, Stockholm.

The Swedish Pension System Annual Report 2003. (2004). Ed. Ole Settergren, National Social Insurance Board (Försäkringskassan), Stockholm.

The Swedish Pension System Annual Report 2004. (2005). Ed. Ole Settergren, Swedish Social Insurance Agency (Försäkringskassan), Stockholm.

The Swedish Pension System Annual Report 2005. (2006). Ed. Ole Settergren, Swedish Social Insurance Agency (Försäkringskassan), Stockholm.

The Swedish Pension System. Orange Annual Report 2006. (2007). Ed. Ole Settergren, Swedish Social Insurance Agency (Försäkringskassan), Stockholm.

Valdés-Prieto, S. (2000). "The Financial Stability of Notional Account Pensions". Scandinavian Journal of Economics, 102 (3), 395-417.

Valdés-Prieto, S. (2002). Políticas y mercados de pensiones. Ediciones Universidad Católica de Chile, Santiago de Chile.

Valdés-Prieto, S. (2005). "Securitization of taxes implicit in PAYG pensions", Economic Policy 20 (4), 215-265

Valdés-Prieto, S. (2006). "Política fiscal y gasto en pensiones mínimas y asistenciales". Estudios Públicos, 103, 43-110.

Vicente, A. E. Pociello and J. Varea (2003). “Análisis dinámico de la invalidez: aplicación a los seguros de riesgo" Actuarios, 21 201-224

Vidal-Meliá, C. and I. Domínguez-Fabián (2006). "The Spanish Pension System: Issues of Introducing Notional Defined Contribution Accounts" In Pension Reform: Issues and Prospects for Notional Defined Contribution (NDC) Schemes, ed. R. Holzmann and E. Palmer, chapter 23. Washington, DC: World Bank.

Vidal-Meliá, C., I. Domínguez-Fabián and J. E. Devesa-Carpio (2006). "Subjective Economic Risk to beneficiaries in Notional Defined Contribution Accounts (NDC's)". The Journal of Risk and Insurance, 73 (3), 489-515.

\section{Appendix 1: The contribution asset}

Consider a steady state where participants' lives last $\left(\mathrm{w}-\mathrm{x}_{\mathrm{e}}\right)$ periods, where $\mathrm{w}$ is the highest age to which it is possible to survive (110 years or more according to recent mortality tables) and $x_{e}$ is the age of entry into the system. In this case, A generations of contributors and ( $w-x_{e}-$ A) generations of pensioners coexist at each moment in time, and a period should be interpreted as one calendar year.

It is considered a demographic and economic environment where the demographic structure is stable in time, i.e. the birth and death rates remain unchanged over time and there are no migratory exchanges. A stable population implies that the relative weight of any age group $\mathrm{x}$ remains or is kept constant, i.e. the relative size of the different cohorts does not change over time. 
A simple case is supposed, where average covered salaries and the contribution base grow at an annual rate of $\mathrm{g} \%$. This growth is assumed to be due entirely to changes in average real salaries, in other words fertility-driven population growth is assumed to be zero $(\gamma=0)$. We assume this because the case for general $\gamma$ has already been solved by Settergren and Mikula (2005, their equation. 7.7 and Annex C).

As too much generality would complicate our notation and reduce the transparency of our results, it is also assumed here that the age-earnings profile or wage pattern is flat, that the rate of pension indexation is zero in real terms and that the age-retirement pattern is cliff-shaped, meaning that all persons of each given generation are assumed to start full pensions and to retire fully at the same age. Average salaries increase in real terms over time if $g>0$, and salaries fall in real terms over time if $\mathrm{g}<0$. Together with the previous assumptions, and assuming a fixed ratio of covered earnings to GDP, these assumptions imply that real GDP also grows (decreases) at rate $\mathrm{g}$.

The parameters of the pension system are considered to be in a stationary state (fixed over time). Both the age giving entitlement to a retirement pension, " $\mathrm{x}_{\mathrm{e}}+\mathrm{A}$ ", and the formula used for calculating the pension are constant, leading to a fixed replacement rate of size $\beta$.

In this triple stationary state, which has both demographic and economic aspects and fixed parameters for the pension system, the demographic-financial structure at any moment $t$ since the start of the system is:

\begin{tabular}{|c|c|c|}
\hline Age & $\underline{\text { Number of contributors }}$ & $\underline{\text { Average salary }}$ \\
\hline $\mathrm{x}_{\mathrm{e}}$ & $\mathrm{N}_{\mathrm{xe}}$ & $\mathrm{y}_{\mathrm{xe}, \mathrm{t}}=\mathrm{y}_{\mathrm{xe}, 1}(1+\mathrm{g})^{\mathrm{t}-1}$ \\
\hline$x_{e}+1$ & $\mathrm{~N}_{\mathrm{xe}+1}$ & $\mathrm{y}_{(\mathrm{xe}+1), \mathrm{t}}=\mathrm{y}_{(\mathrm{xe}+1), 1}(1+\mathrm{g})^{\mathrm{t}-1}$ \\
\hline · & . & · \\
\hline . & · & · \\
\hline & $\cdot$ & . \\
\hline $\mathrm{x}_{\mathrm{e}}+\mathrm{A}-1$ & $\mathrm{~N}_{\mathrm{xe}+\mathrm{A}-1}$ & $\mathrm{y}_{(\mathrm{xe}+\mathrm{A}-1), \mathrm{t}}=\mathrm{y}_{(\mathrm{xe}+\mathrm{A}-1), 1}(1+\mathrm{g})^{\mathrm{t}-1}$ \\
\hline
\end{tabular}

The highest age for any member of the group, at which there are no longer any survivors, is defined as " $w$ ". Therefore, from date " $w-\mathrm{x}_{\mathrm{e}}-\mathrm{A}$ " counted from the start of the system, the probability that an individual of age " $\mathrm{x}_{\mathrm{e}}+\mathrm{A}$ " will reach age " $\mathrm{w}$ " is zero. In addition, all survival probabilities from that year onwards are also zero for that cohort.

${ }_{w-x e-A} p_{x e+A}$ : Probability that an individual of age " $\mathrm{x}_{\mathrm{e}}+\mathrm{A}$ " will reach the age limit $\mathrm{w}$, verifies: $0={ }_{w-x-A} p_{x e+A}={ }_{w-x e-A+1} p_{x e+A}={ }_{w-x e-A+2} p_{x e+A}=\ldots$

From this year onwards the population of participants is in a stationary state.

The annual retirement pension is $\beta \cdot \mathrm{Y}_{\mathrm{C}, \mathrm{t}}$, which is calculated as a set percentage $\beta$ of the average salaries by taking into account the 15 years before retirement, $\mathrm{Y}_{\mathrm{C}, \mathrm{t}}$. This benefit formula represents the one used in the Spanish pension system. This pension is a constant real amount per year. It is also assumed that all persons in a generation start full pensions and retire fully at the same age.

Given cash-flow equilibrium at all dates, the value of the liabilities of the pension system is equal to the value of the assets regardless of the level and sequence of discount rates. If in addition we assume that the system does not have financial assets protected by property rights, the only possible remaining asset is the Contribution Asset. This makes it unnecessary to calculate the assets independently, starting from cash flows, in contrast to what is done in the Hidden Asset approach. For a known liability, the size of the Contribution Asset follows directly, because under these conditions it must be equal to the liability.

The contribution rate that exactly achieves financial equilibrium is aggregate benefit 
expenditure divided by the aggregate contribution base:

(7.)

$\theta_{w-x e-A}=\frac{\beta Y_{C, 1} \sum_{\mathrm{k}=0}^{w-x e-A-1} N_{x e+A+k}(1+\mathrm{g})^{w-x e-A-1-k}}{(1+\mathrm{g})^{w-x e-A-1} \sum_{\mathrm{k}=0}^{\mathrm{A}-1} \mathrm{y}_{(\mathrm{xe}+\mathrm{k}), 1} N_{\mathrm{xe}+\mathrm{k}}}=\frac{\beta Y_{C, 1} \sum_{\mathrm{k}=0}^{w-x e-A-1} N_{x e+A+k}(1+\mathrm{g})^{-k}}{\sum_{\mathrm{k}=0}^{\mathrm{A}-1} \mathrm{y}_{(\mathrm{xe}+\mathrm{k}), 1} N_{\mathrm{xe}+\mathrm{k}}}=\theta_{w-x_{e}-A+1}=\ldots=\theta$

$N_{\text {Xe+A }}$ : Number of people who reach retirement at the normal age " $x_{e}+A$ " in each year; under the stated hypotheses this number is constant in time.

The required contribution rate from year " $\mathrm{w}-\mathrm{x}_{\mathrm{e}}-\mathrm{A}$ " onwards (counted from the start of the system) is constant from the actuarial point of view because, from that moment on, the number of deaths of people in receipt of retirement pensions (number of retirees leaving) during that year is equal to the number of people that retire during that year (number of retirees entering), and therefore the number of retirees remains constant.

Now it is calculated the system's liabilities starting from cash flows. They comprise those with current pensioners and those with current contributors.

Liabilities with current pensioners in the stationary state are equal to:

$$
V_{w-X_{e}-A}^{r(g>o)}=\beta Y_{C, 1} \sum_{\mathrm{k}=0}^{\mathrm{W}-\mathrm{Xe}-\mathrm{A}-1} N_{X e+A+k} \ddot{a}_{x e+A+k}(1+g)^{w-x_{e}-A-1-k}
$$

$\ddot{a}_{x e+A+k}$ being the actuarial value of a lifetime pension payable in advance and valued at the age of " $\mathrm{x}_{\mathrm{e}}+\mathrm{A}+\mathrm{k}$ " years with a technical interest rate equal to $\mathrm{d}=\mathrm{g}$.

The liabilities with contributors will be constant and equal to:

(9.)

$V_{w-x e-A}^{c(g>0)}=\overbrace{\beta Y_{C, 1} N_{X e+A} \ddot{a}_{x e+A} \sum_{h=1}^{A}(1+g)^{w-x e-A+h-1}(1+d)^{-h}}^{\text {Future pensions }}-\underbrace{\theta \sum_{\mathrm{k}=0}^{A-1} \sum_{\mathrm{h}=0}^{k} N_{\mathrm{xc}+\mathrm{k}} \mathrm{y}_{(\mathrm{xe}+\mathrm{k}), 1}(1+\mathrm{g})^{w-x e-A+h-1}(1+d)^{-h}}_{\text {Future contributions }}$

According to Settergren and Mikula (2005), to obtain the turnover duration, total liabilities are divided by the annual contribution flow, leading to:

(10.)

$$
\begin{gathered}
\frac{V_{w-x_{e}-A}^{t(g>0)}}{C_{w-x e-A}} \equiv T D^{t(g>0)}=\frac{\sum_{\mathrm{k}=0}^{\mathrm{w}-\mathrm{xc}-\mathrm{A}-1} N_{x e+A+k} \ddot{a}_{x e+A+k}(1+\mathrm{g})^{-k}}{\sum_{\mathrm{k}=0}^{\mathrm{w}-\mathrm{xe}-\mathrm{A}-1} N_{x e+A+k}(1+\mathrm{g})^{-k}}+\frac{N_{x e+A} \ddot{a}_{x e+A} \sum_{h=1}^{A}(1+\mathrm{g})^{h}(1+d)^{-h}}{\sum_{\mathrm{k}=0}^{w-x e-A-1} N_{x e+A+k}(1+\mathrm{g})^{-k}} \\
-\frac{\sum_{\mathrm{k}=0}^{\mathrm{A}-1} \sum_{\mathrm{h}=0}^{k} N_{\mathrm{xc}+\mathrm{k}} \mathrm{y}_{(\mathrm{xe}+\mathrm{k}), 1}(1+\mathrm{g})^{h}(1+d)^{-h}}{\sum_{\mathrm{k}=0}^{\mathrm{A}-1} \mathrm{y}_{(\mathrm{xc}+\mathrm{k}), 1} N_{\mathrm{xc}+\mathrm{k}}}
\end{gathered}
$$


Given the hypothesis $\gamma=0$ adopted in this appendix, the growth rate of GDP is g, the real growth rate in average salaries. The value of the IRR for participants ${ }^{18}$ is also $g$ in this steady state $^{19}$. If it is substituted in the previous formula that $\mathrm{g}=\mathrm{d}=\mathrm{IRR}$, then:

(11.)

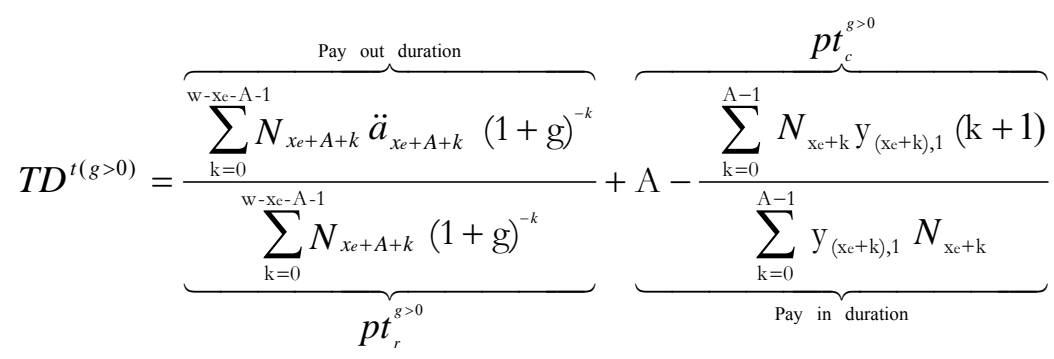

Therefore, the turnover duration total is the sum of the weighted pay-in and pay-out durations of one monetary unit in the system for the year's contributions:

$$
\frac{V_{w-x_{e}-A}^{t(g>0)}}{C_{w-\chi e-A}} \equiv T D^{t(g>0)}=p t_{r}^{g>0}+p t_{c}^{g>0}
$$

if " $\mathrm{x}_{\mathrm{e}}+\mathrm{A}-1$ " years are added to and subtracted from the previous expression, the turnover duration is the difference in average weighted ages of the pensioners and the contributors:

$$
T D^{t(g>0)}=\overbrace{\left(x_{e}+A-1\right)+p t_{r}}^{\text {Average weighted age for the pensioners }}-\underbrace{\left(x_{e}+A-1-p t_{c}\right)}_{\text {Average weighted age for the contributors }}=
$$

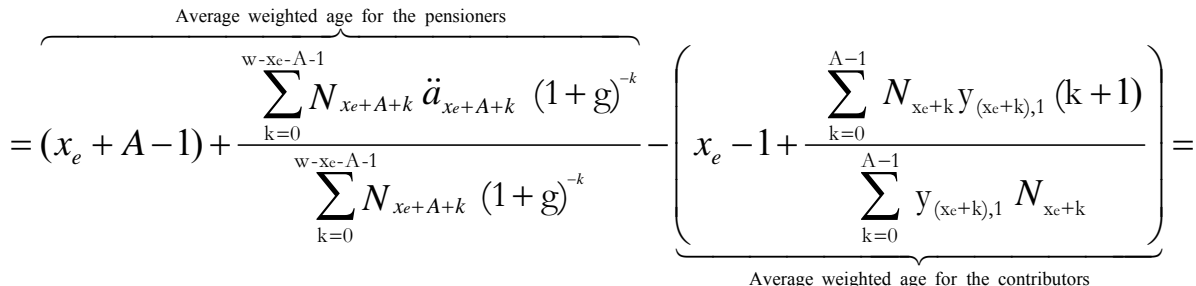

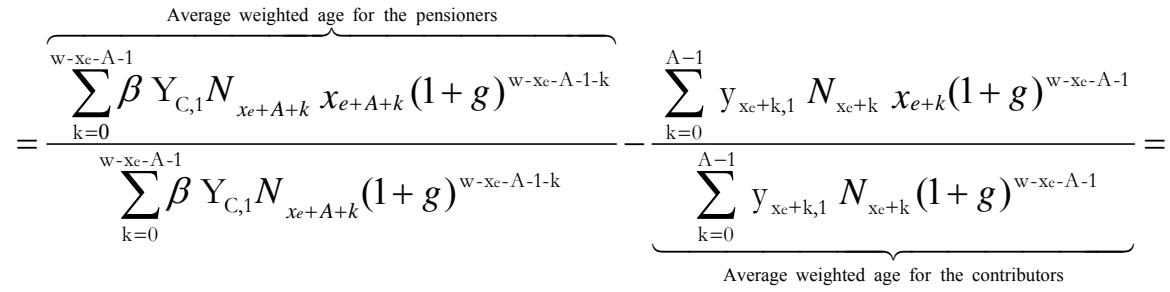

(13.)

$$
=A_{r}^{g>0}-A_{c}^{g>0}
$$

As higher discount rates reduce a present discounted value, for given cash flows, it is clear that:

(14.)

\footnotetext{
${ }^{18}$ The IRR is defined as the value of parameter $\mathrm{i}$ of the law of compound interest, which sets equal to zero the present value of the cash-flows constituted by the aggregate yearly contributions paid by a cohort and the aggregate yearly pension benefits received by the same cohort.

${ }^{19}$ See Samuelson (1958), Aaron (1966) and Gronchi and Nisticò (2003). Gronchi and Nisticò (2007), present a reformulation of the Samuelson-Aaron theorem that recognized the wage bill growth rate as the internal rate of return (IRR) on contributions and the 'sustainable return' of PAYG-DB schemes in a steady growing economy.
} 


$$
\left[C A_{w-x e-A}^{g>0}=C_{w-x e-A}^{g>0} \cdot\left(p t_{r}^{g>0}+p t_{c}^{g>0}\right)=V_{w-x e-A}^{r+c(g>0)}\right]<\left[C A_{w-x-A}^{g=0}=C_{w-x e-A}^{g=0} \cdot\left(p t_{r}^{g=0}+p t_{c}^{g=0}\right)=V_{w-x e-A}^{r+c(g=0)}\right]
$$

\section{Appendix 2: The hidden asset}

This presentation of the concept of the Hidden Asset is based on an initial approach by Valdés-Prieto (2002), who explored the case of a population of overlapping generations in which each generation of members of the system lives for two periods of equal duration, surviving until the second with probability 1 . In the first period the participant contributes fraction $\theta$ of his pensionable earnings and in the second receives a pension. It is supposed that aggregate covered earnings grow at the constant real annual rate of $\mathrm{G} \%$, where $\mathrm{G}=\mathrm{g}+\gamma$ according to our previous notation. There is no assumption as to how $\mathrm{G}$ is formed by growth in average real salaries $(\mathrm{g})$ and fertility-driven population growth $(\gamma)$. The discount rate is the real rate of interest for safe assets observed in the economy and possibly in the financial markets is $\mathrm{r} \%$ per period. It is also assumed that $\mathrm{r}>\mathrm{G}$. It is also supposed that the economy and the pension system are in a stationary state, and therefore all these parameters are constant in time. However, this steady state is not of the "golden rule" type, because $r>G$.

The tax or excess contributions paid by each participant in the pension system is the difference between the present value of the contributions made and the value of the pensions received. Therefore the aggregate " $T$ " of the taxes or excess contributions charged to each generation of participants during their working period is:

$$
T(t)=\left(\theta-\frac{\beta}{1+r}\right) y(t) \cdot N(t)
$$

Where:

$N(t)$, number of working participants ("young people") in period t; $y(t)$, pensionable earnings of the workers in $\mathrm{t}$, and $\beta$, replacement rate that the system gives in the second period of life.

In a stationary state where the degree of funding $\phi$ is constant in time, ( $\phi$ can be positive, as in the case of Sweden, but less than 1 as long as funding is not full), cash-flow equilibrium in the absence of sponsor contributions requires that (Valdés-Prieto 2002, eq. (8.7)):

$$
\theta=\beta \cdot\left[\frac{\phi}{1+r}+\frac{1-\phi}{1+G}\right]
$$

If the system is financed by pure pay-as-you-go, the degree of funding is zero $(\phi=0)$, and Equation (16) becomes:

$$
\theta=\frac{\beta}{1+G}=\frac{\beta}{1+I R R}
$$

In the general case for intermediate degrees of funding, the aggregate tax or aggregate excess contribution is obtained by inserting (16) into (15). During period t the aggregate tax revenue is the amount:

$$
T(t+i)=y(t+i) \cdot N(t+i) \cdot \beta \cdot(1-\phi) \cdot \frac{(r-G)}{(1+r)(1+G)}
$$

These taxes (excess contributions) are an economic asset for the pension system, although not protected by property rights. As each generation of future participants has to contribute more than the present value of the pensions that will be awarded to them, the system obtains a profit from "serving" future generations.

The present value of the taxes that will be paid by all future generations of participants to the system, considering that aggregate pensionable earnings $(y(t+j) \cdot N(t+j))$ grow at rate $G$, is defined as the Hidden Asset of the pension system: 
(19.)

$H A \equiv \sum_{i=0}^{\infty} \frac{T(t+i)}{(1+r)^{i}}=\frac{\frac{(y(t) \cdot N(t)) \beta \cdot(1-\phi) \cdot(r-G)}{(1+G)(1+r)}}{1-\frac{(1+G)}{(1+r)}}=\underbrace{\frac{\beta \cdot y(t) \cdot N(t)}{1+G}}_{\text {Pensions paid to the first generation }} \quad(1-\phi)$

Equation (19) shows that the present discounted value of future taxes is equal to the pension payments to the first generation. This result was proved before and independently for the case $\phi=0$ by Lüdecke (1988), Geanakoplos et al. (1998) and by Sinn (1990, 2000), all of whom discuss its policy implications. Equation (19) extends this result to the case of partial funding $(\phi>0)$. Under partial funding the Hidden Asset is equal to the subsidy received by the first generation, which is less than the pension payments received by that generation because some of their contributions were saved to form the fund.

Another result emphasized by Valdes-Prieto (2002) is that the right hand-side expression, plus financial assets, whose value by definition of $\phi$ is equal to $\phi \frac{\beta \cdot y(t) \cdot N(t)}{1+G}$ at the end of period $\mathrm{t}$, adds up to equal the size of liabilities. This shows that the cash flows related to the hidden tax $\mathrm{T}$ back up the liabilities exactly.

Possibly a more intuitive way of reaching Equation 19 is as follows: The actuarially fair contribution rate, $\theta_{f}$, defined on the basis of the return of the financial market, is defined as $\theta_{f}=\frac{\beta}{1+r}$, and therefore the aggregate " $\mathrm{T}$ " of the taxes or excess contributions charged to each generation of participants, evaluated when they are young, is:

$$
T(t)=\left(\theta-\theta_{f}\right) \cdot y(t) \cdot N(t)
$$

Then the Hidden Asset is:

(21.)

$$
H A=\frac{\left(\theta-\theta_{f}\right) \cdot y(t) \cdot N(t) \cdot(1+r)}{r-G}=\overbrace{\theta \cdot y(t) \cdot N(t)}^{\text {Contributions paid by the first generation }} \cdot \frac{1}{1+\left(\frac{\phi}{1-\phi} \cdot \frac{1+G}{1+r}\right)}
$$

Expression (21) shows that in the specific case of pure pay-as-you-go $(\phi=0)$ the Hidden Asset is equal to the contributions paid by the first generation. However, if there is partial funding as in Sweden $(\phi>0)$, the Hidden Asset is necessarily less than the contributions paid by the first generation. 
Appendix 3: Sensitivity analysis of the Spanish actuarial balance sheet with regard to changes in the projected growth rate of average real salaries (g).

\begin{tabular}{|c|c|c|c|c|c|c|}
\hline \multicolumn{7}{|c|}{$\begin{array}{c}\text { TABLE } 5 \\
\text { Balance sheet at Dec. } 31 \text { of each year for the Spanish pension system as \% of GPD. Consolidated for all } \\
\text { regimes. }\end{array}$} \\
\hline Year & 2006 & 2005 & 2004 & 2003 & 2002 & 2001 \\
\hline \multicolumn{7}{|c|}{ ASSETS } \\
\hline Financial Asset & 3.68 & 3.00 & 2.30 & 1.54 & 0.85 & 0.36 \\
\hline Contribution Asset & 125.40 & 124.32 & 124.03 & 126.61 & 127.15 & 131.28 \\
\hline Accumulated Deficit & 56.83 & 59.00 & 52.80 & 51.02 & 44.92 & 48.12 \\
\hline "Losses for the period" & 2.56 & 2.27 & 10.78 & 5.67 & 9.83 & 0.00 \\
\hline Total Assets & 188.47 & 188.59 & 189.92 & 184.83 & 182.74 & 179.76 \\
\hline \multicolumn{7}{|c|}{ LIABILITIES } \\
\hline Liability to Pensioners & 53.19 & 53.92 & 53.82 & 54.60 & 56.06 & 55.18 \\
\hline Liability to Contributors & 135.28 & 134.67 & 136.10 & 130.23 & 126.68 & 124.58 \\
\hline Total Liabilities & 188.47 & 188.59 & 189.92 & 184.83 & 182.74 & 179.76 \\
\hline \multicolumn{7}{|c|}{ FUNDING AND SOLVENCY INDICATORS } \\
\hline Ratio of (in)solvency & 0.685 & 0.675 & 0.665 & 0.693 & 0.700 & 0.732 \\
\hline (Degree of funding)\% & 1.95 & 1.59 & 1.21 & 0.83 & 0.46 & 0.20 \\
\hline $\begin{array}{c}\text { (Liabilities to } \\
\text { Contrib./Liabilities)\% }\end{array}$ & 71.78 & 71.41 & 71.66 & 70.46 & 69.32 & 69.30 \\
\hline \multicolumn{7}{|c|}{ IRR $=g=d=1.5 \%$} \\
\hline
\end{tabular}

\begin{tabular}{|c|c|c|c|c|c|c|}
\hline \multicolumn{7}{|c|}{$\begin{array}{c}\text { TABLE } 6 \\
\text { Balance sheet at Dec. } 31 \text { of each year for the Spanish pension system as \% of GPD. Consolidated for all } \\
\text { regimes. }\end{array}$} \\
\hline Year & 2006 & 2005 & 2004 & 2003 & 2002 & 2001 \\
\hline \multicolumn{7}{|c|}{ ASSETS } \\
\hline Financial Asset & 3.68 & 3.00 & 2.30 & 1.54 & 0.85 & 0.36 \\
\hline Contribution Asset & 68.77 & 68.40 & 68.08 & 67.86 & 66.49 & 67.19 \\
\hline Accumulated Deficit & 32.49 & 33.84 & 30.34 & 29.14 & 25.81 & 27.65 \\
\hline "Losses for the period" & 0.79 & 1.18 & 6.14 & 3.43 & 5.46 & 0.00 \\
\hline Total Assets & 105.73 & 106.43 & 106.86 & 101.96 & 98.61 & 95.20 \\
\hline \multicolumn{7}{|c|}{ LIABILITIES } \\
\hline Liability to Pensioners & 47.61 & 48.27 & 48.20 & 48.88 & 50.18 & 49.51 \\
\hline Liability to Contributors & 58.12 & 58.16 & 58.66 & 53.08 & 48.43 & 45.69 \\
\hline Total Liabilities & 105.73 & 106.43 & 106.86 & 101.96 & 98.61 & 95.20 \\
\hline \multicolumn{7}{|c|}{ FUNDING AND SOLVENCY INDICATORS } \\
\hline Ratio of (in)solvency & 0.685 & 0.671 & 0.659 & 0.681 & 0.683 & 0.710 \\
\hline (Degree of funding)\% & 3.48 & 2.82 & 2.15 & 1.51 & 0.86 & 0.38 \\
\hline $\begin{array}{c}\text { (Liabilities to } \\
\text { Contrib./Liabilities)\% }\end{array}$ & 54.97 & 54.65 & 54.89 & 52.06 & 49.11 & 47.99 \\
\hline \multicolumn{7}{|c|}{ IRR $=g=d=3 \%$} \\
\hline
\end{tabular}

When working with the real data for a year, whatever the real system may be, sensitivity analysis is subject to a serious restriction: the amount of a given year's contributions cannot be changed. This implies that the TD for the various scenarios where $\mathrm{d}=\mathrm{g}>0$ has to be obtained as a reference with respect to the assumption $\mathrm{d}=\mathrm{g}=0$ based on the new value of the liability. This restriction does not appear in the theory provided in Appendix 1, where for any given replacement rate $(\beta)$ the system is assumed to automatically adjust the contribution rate $\theta$ to 
reach cash-flow equilibrium. In this theoretical scenario, sensitivity analyses include an endogenous contribution rate. This is a fundamental difference between the theoretical case of Appendix 1 and any real pension system.

In Tables 5 and 6 , financial assets are reported at their current market value in all growth scenarios. These simulations show the impact of a simultaneous, permanent and equal change in the discount rate and in the average real salary growth rate. This type of change is required by the requirements imposed by the contribution asset methodology.

The important result is that the solvency ratio change very little between tables 5 and 6 , despite much larger changes in the value of assets and liabilities as a proportion of GDP. 
Appendix 4: Data and calculation variables for the Spanish regimes considered

Data variables detailed by regime are available upon request, from the corresponding autor.

\begin{tabular}{|c|c|c|c|c|c|c|}
\hline \multicolumn{7}{|c|}{$\begin{array}{c}\text { TABLE } 7 \\
\text { Main data and variables. All regimes. }\end{array}$} \\
\hline Items & 2001 & 2002 & 2003 & 2004 & 2005 & 2006 \\
\hline Contributors (average) & $15,649,891$ & $16,126,264$ & $16,613,517$ & $17,081,700$ & $17,835,435$ & $18,596,345$ \\
\hline $\begin{array}{l}\text { Contributions (ret) } \\
\text { Millions of euros }\end{array}$ & 39,029 & 41,232 & 44,004 & 46,229 & 49,815 & 54,528 \\
\hline $\begin{array}{l}\text { Real contributions (ret) } \\
\text { Millions of euros } 2006\end{array}$ & 45,548 & 46,402 & 48,408 & 49,327 & 51,011 & 54,528 \\
\hline $\begin{array}{c}\text { Average annual contribution } \\
\text { Euros/year } \\
\end{array}$ & 2,494 & 2,557 & 2,649 & 2,706 & 2,793 & 2,932 \\
\hline $\begin{array}{c}\text { Real average annual contribution } \\
\text { Euros/year } 2006\end{array}$ & 2,910 & 2,877 & 2,914 & 2,888 & 2,860 & 2,932 \\
\hline Retirement contribution rate $\%$ & 19.02 & 18.94 & 18.80 & 18.55 & 18.58 & 18.66 \\
\hline Retirement pensioners & $4,508,665$ & $4,537,926$ & $4,562,358$ & $4,580,093$ & $4,722,537$ & $4,787,949$ \\
\hline $\begin{array}{c}\text { Average annual pension } \\
\text { Euros/year } \\
\end{array}$ & 8,211 & 8,601 & 8,989 & 9,529 & 10,010 & 10,522 \\
\hline $\begin{array}{c}\text { Real average annual pension } \\
\text { Euros/year } 2006 \\
\end{array}$ & 9,582 & 9,679 & 9,889 & 10,167 & 10,250 & 10,522 \\
\hline Ar (Age) & 73.95 & 73.32 & 73.44 & 73.56 & 73.71 & 73.78 \\
\hline Ac (Age) & 39.85 & 39.96 & 40.13 & 40.35 & 40.43 & 40.48 \\
\hline TD (years) & 34.10 & 33.36 & 33.30 & 33.21 & 33.28 & 33.30 \\
\hline
\end{tabular}




\section{CESifo Working Paper Series}

for full list see www.cesifo-group.org/wp

(address: Poschingerstr. 5, 81679 Munich, Germany, office@cesifo.de)

2120 Stefan Napel and Mika Widgrén, The European Commission - Appointment, Preferences, and Institutional Relations, October 2007

2121 Bertil Holmlund and Martin Söderström, Estimating Income Responses to Tax Changes: A Dynamic Panel Data Approach, October 2007

2122 Doina Maria Radulescu, From Separate Accounting to Formula Apportionment: Analysis in a Dynamic Framework, October 2007

2123 Jelle Brouwer, Richard Paap and Jean-Marie Viaene, The Trade and FDI Effects of EMU Enlargement, October 2007

2124 Kurt R. Brekke, Luigi Siciliani and Odd Rune Straume, Competition and Waiting Times in Hospital Markets, October 2007

2125 Alexis Direr, Flexible Life Annuities, October 2007

2126 Johannes Becker and Clemens Fuest, Quality versus Quantity - The Composition Effect of Corporate Taxation on Foreign Direct Investment, October 2007

2127 Balázs Égert, Real Convergence, Price Level Convergence and Inflation Differentials in Europe, October 2007

2128 Marko Koethenbuerger, Revisiting the "Decentralization Theorem" - On the Role of Externalities, October 2007

2129 Axel Dreher, Silvia Marchesi and James Raymond Vreeland, The Politics of IMF Forecasts, October 2007

2130 Andreas Knabe and Ronnie Schöb, Subsidizing Extra Jobs: Promoting Employment by Taming the Unions, October 2007

2131 Michel Beine and Bertrand Candelon, Liberalization and Stock Market Co-Movement between Emerging Economies, October 2007

2132 Dieter M. Urban, FDI Technology Spillovers and Wages, October 2007

2133 Valentina Bosetti, Carlo Carraro, Emanuele Massetti and Massimo Tavoni, Optimal Energy Investment and R\&D Strategies to Stabilise Greenhouse Gas Atmospheric Concentrations, October 2007

2134 David-Jan Jansen and Jakob de Haan, The Importance of Being Vigilant: Has ECB Communication Influenced Euro Area Inflation Expectations?, October 2007 
2135 Oliver Falck, Heavyweights - The Impact of Large Businesses on Productivity Growth, October 2007

2136 Xavier Freixas and Bruno M. Parigi, Banking Regulation and Prompt Corrective Action, November 2007

2137 Jan K. Brueckner, Partial Fiscal Decentralization, November 2007

2138 Silvia Console Battilana, Uncovered Power: External Agenda Setting, Sophisticated Voting, and Transnational Lobbying, November 2007

2139 Alan J. Auerbach, Michael P. Devereux and Helen Simpson, Taxing Corporate Income, November 2007

2140 Lorenzo Cappellari, Paolo Ghinetti and Gilberto Turati, On Time and Money Donations, November 2007

2141 Roel Beetsma and Heikki Oksanen, Pension Systems, Ageing and the Stability and Growth Pact, November 2007

2142 Hikaru Ogawa and David E. Wildasin, Think Locally, Act Locally: Spillovers, Spillbacks, and Efficient Decentralized Policymaking, November 2007

2143 Alessandro Cigno, A Theoretical Analysis of the Effects of Legislation on Marriage, Fertility, Domestic Division of Labour, and the Education of Children, November 2007

2144 Kai A. Konrad, Mobile Tax Base as a Global Common, November 2007

2145 Ola Kvaløy and Trond E. Olsen, The Rise of Individual Performance Pay, November 2007

2146 Guglielmo Maria Caporale, Yannis Georgellis, Nicholas Tsitsianis and Ya Ping Yin, Income and Happiness across Europe: Do Reference Values Matter?, November 2007

2147 Dan Anderberg, Tax Credits, Income Support and Partnership Decisions, November 2007

2148 Andreas Irmen and Rainer Klump, Factor Substitution, Income Distribution, and Growth in a Generalized Neoclassical Model, November 2007

2149 Lorenz Blume, Jens Müller and Stefan Voigt, The Economic Effects of Direct Democracy - A First Global Assessment, November 2007

2150 Axel Dreher, Pierre-Guillaume Méon and Friedrich Schneider, The Devil is in the Shadow - Do Institutions Affect Income and Productivity or only Official Income and Official Productivity?, November 2007

2151 Valentina Bosetti, Carlo Carraro, Emanuele Massetti and Massimo Tavoni, International Energy R\&D Spillovers and the Economics of Greenhouse Gas Atmospheric Stabilization, November 2007 
2152 Balázs Égert and Dubravko Mihaljek, Determinants of House Prices in Central and Eastern Europe, November 2007

2153 Christa Hainz and Hendrik Hakenes, The Politician and his Banker, November 2007

2154 Josef Falkinger, Distribution and Use of Knowledge under the "Laws of the Web", December 2007

2155 Thorvaldur Gylfason and Eduard Hochreiter, Growing Apart? A Tale of Two Republics: Estonia and Georgia, December 2007

2156 Morris A. Davis and François Ortalo-Magné, Household Expenditures, Wages, Rents, December 2007

2157 Andreas Haufler and Christian Schulte, Merger Policy and Tax Competition, December 2007

2158 Marko Köthenbürger and Panu Poutvaara, Rent Taxation and its Intertemporal Welfare Effects in a Small Open Economy, December 2007

2159 Betsey Stevenson, Title IX and the Evolution of High School Sports, December 2007

2160 Stergios Skaperdas and Samarth Vaidya, Persuasion as a Contest, December 2007

2161 Morten Bennedsen and Christian Schultz, Arm’s Length Provision of Public Services, December 2007

2162 Bas Jacobs, Optimal Redistributive Tax and Education Policies in General Equilibrium, December 2007

2163 Christian Jaag, Christian Keuschnigg and Mirela Keuschnigg, Pension Reform, Retirement and Life-Cycle Unemployment, December 2007

2164 Dieter M. Urban, Terms of Trade, Catch-up, and Home Market Effect: The Example of Japan, December 2007

2165 Marcelo Resende and Rodrigo M. Zeidan, Lionel Robbins: A Methodological Reappraisal, December 2007

2166 Samuel Bentolila, Juan J. Dolado and Juan F. Jimeno, Does Immigration Affect the Phillips Curve? Some Evidence for Spain, December 2007

2167 Rainald Borck, Federalism, Fertility and Growth, December 2007

2168 Erkki Koskela and Jan König, Strategic Outsourcing, Profit Sharing and Equilibrium Unemployment, December 2007

2169 Egil Matsen and Øystein Thøgersen, Habit Formation, Strategic Extremism and Debt Policy, December 2007 
2170 Torben M. Andersen and Allan Sørensen, Product Market Integration and Income Taxation: Distortions and Gains from Trade, December 2007

2171 J. Atsu Amegashie, American Idol: Should it be a Singing Contest or a Popularity Contest?, December 2007

2172 Patricia Apps and Ray Rees, Household Models: An Historical Perspective, December 2007

2173 Ben Greiner, Axel Ockenfels and Peter Werner, The Dynamic Interplay of Inequality and Trust - An Experimental Study, December 2007

2174 Michael Melvin and Magali Valero, The Dark Side of International Cross-Listing: Effects on Rival Firms at Home, December 2007

2175 Gebhard Flaig and Horst Rottmann, Labour Market Institutions and the Employment Intensity of Output Growth. An International Comparison, December 2007

2176 Alexander Chudik and M. Hashem Pesaran, Infinite Dimensional VARs and Factor Models, December 2007

2177 Christoph Moser and Axel Dreher, Do Markets Care about Central Bank Governor Changes? Evidence from Emerging Markets, December 2007

2178 Alessandra Sgobbi and Carlo Carraro, A Stochastic Multiple Players Multi-Issues Bargaining Model for the Piave River Basin, December 2007

2179 Christa Hainz, Creditor Passivity: The Effects of Bank Competition and Institutions on the Strategic Use of Bankruptcy Filings, December 2007

2180 Emilia Del Bono, Andrea Weber and Rudolf Winter-Ebmer, Clash of Career and Family: Fertility Decisions after Job Displacement, January 2008

2181 Harald Badinger and Peter Egger, Intra- and Inter-Industry Productivity Spillovers in OECD Manufacturing: A Spatial Econometric Perspective, January 2008

2182 María del Carmen Boado-Penas, Salvador Valdés-Prieto and Carlos Vidal-Meliá, The Actuarial Balance Sheet for Pay-As-You-Go Finance: Solvency Indicators for Spain and Sweden, January 2008 